\title{
The Mismatch Between State Power and State Capacity in \\ Transnational Law Enforcement
}

\author{
By \\ Mariano-Florentino Cuéllar*
}

Introduction

I. The Global Attack on Criminal Finance as a Case Study in

Transnational Law Enforcement.................... 21

A. Legal Structure of the Attack on Criminal Finance....... 21

B. The Role of Treaties and Extraterritorial Power......... 27

1. Justifications for Making the Attack Global ........ 27

2. International Agreements ................... 30

3. Extraterritorial Power...................... 32

C. A Proliferation of Laws Targeting Criminal Finance ..... 35

II. The Mismatch Between State Power and State Capacity ...... 39

A. Power and Capacity Distinguished................ 40

B. The Forces Creating a Power-Capacity Mismatch ....... 41

1. The Impact of Detection Difficulties ............ 41

2. Uncertain Impact of Legal Changes in Reluctant

States ............................. 42

3. Political Incentives to Use Power Without Capacity in Developed Countries ...................... 44

4. Substitution $\ldots \ldots \ldots \ldots \ldots \ldots \ldots \ldots \ldots \ldots \ldots, 48$

III. The Potential Consequences of the Mismatch............ 49

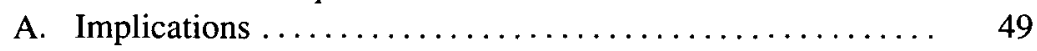

B. Prospects for Controlling the Mismatch ............ 54

Conclusion ................................... 56

Appendix: Signaling Capacity With a Divided Electorate and

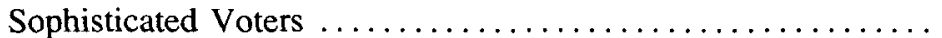

If there were but one way to wage war against crime, and the only question how vigorously to do it, there would be no need to identify the different objectives in devising the campaign. But if this is a continual campaign to cope with

* Assistant Professor, Stanford Law School. Thanks to Bob Weisberg, Mark Kelman, Lawrence Friedman, and participants at a social science research workshop of the Stanford Center for International Security and Cooperation for their insights. I also thank the editors of the Berkeley Journal of International Law for helpful editorial assistance. Please send comments to tcuellar@stanford.edu. This article is dedicated to Snoopie. Any mismatch between what is correct and what is in here is solely the author's responsibility. 
some pretty definite evils, without any real expectation of total victory or unconditional surrender, resources have to be allocated and deployed in a way that maximizes the value of a compromise. ${ }^{1}$

\section{INTRODUCTION}

Imagine that the citizens of a nation-state fear an amorphous threat to their security. Maybe the threat emerges from a tide of corruption, fraud, or drug trafficking. Perhaps the citizens fear a growing threat of terrorist activity. In response to citizens' concerns, the government recognizes the threat and uses its legal powers to respond. If existing laws are not sufficient, the government promulgates new laws that increase its capacity to deal with the threat. When these threats spill across borders, states cooperate on investigations, craft international treaties, or assert extraterritorial legal authority to seize an offender. Over time, governments therefore reduce both domestic and transnational threats.

I take issue with this account. The power to impose coercive punishment through law and the capacity to reduce threats are different things. Power reflects a nation-state's authority to legitimately coerce individuals or organizations in an attempt to achieve some objective desired by policymakers. The hallmarks of power are expansively-worded criminal statutes that can be applied domestically or extraterritorially and extensive regulatory powers that can be imposed with minimal judicial intervention to detain people, effect forfeitures of bank accounts, freeze assets or impose civil penalties. Capacity, meanwhile, describes the nation-state's ability to detect the most serious offenders and to effectively focus its extraordinary legal powers specifically on them. ${ }^{2}$ Capacity is not assured with the passage of any law. It depends on the interplay between the laws, the behavior of the targets of law enforcement, and the technical sophistication, political incentives, and organizational practices of law enforcement officials and their political superiors. Together these practices let the nation-state anticipate how offenders behave, and in particular, how they react to the law. The separation between capacity and power can cloud analysis of the law's role in reducing transnational threats, creating agency problems that sepa-

1. Thomas Schelling, Choice and Consequence 169 (1984).

2. Obviously a lot here depends on how we define "serious," "important," or "egregious" offenders. For the purposes of this article, I assume that one can ordinally sort offenders into groups, where the most serious ones are those that fall into either of two categories: those most resembling the paradigmatic offenders used by supporters of a particular law enforcement program to justify that program, or those who have a combination of motivation and ability to carry out (or substantially facilitate) activities that laypeople might find particularly troubling. These might include, among others, detonating a dirty bomb, leading and expanding an organized criminal network involving narcotics trafficking or alien smuggling, or engaging in massive public corruption schemes involving the theft of large sums from the public fisc. Constructing such an ordinal ranking of offense severity is relatively straightforward using the public statements of policymakers or reactions from the public. Creating a cardinal ranking is more difficult. See, e.g., Peter Rossi et al., The Seriousness of Crimes: Normative Structure and Individual Differences, 39 AM. Soc. REv. 224, 227 (1974). 
rate the interests of the public at large (the "principal") from those of politicians running the government (the "agent"). ${ }^{3}$

Why would policymakers not care about capacity? Even if some want to do their best to build capacity, nothing guarantees that legislators, executive branch officials, and law enforcement officials will care about capacity-building, particularly when it is so easy for the public to observe the use of government legal powers and so hard for the public to observe just how much capacity the nation-state has to reduce threats at the margin. ${ }^{4}$ Suppose that some important segment of the national public wanted to force its government to develop capacity and they had some way to put pressure on the government. If all the laws addressing transnational threats then could be precisely, and publicly, probed with an uncontroversial metric of marginal costs and benefits, there would be little danger of a gap between power and capacity. The public or political intermediaries such as opposition politicians could then clearly assess government capacity. That metric is not available, and is unlikely to appear anytime soon. ${ }^{5}$ Marginal reductions in atrocious transnational threats may be desirable if they can be achieved through expansions in the nation-state's legal power. However, such a trade-off still requires us to evaluate, rather than assume, the connection between power and capacity.

My purpose here is to analyze the forces that engender the separation of state capacity and state power in order to shed light on transnational criminal justice. I have chosen the global attack on criminal finance as a case study because it is the most ambitious legal response to transnational crime: the conduct targeted in this attack includes both willful and also merely negligent conduct, the tools used to wage the attack include criminal penalties as well as regulation, and the predicate offenses range from drug trafficking to public cor-

3. Cf. Jeffrey S. Banks \& Barry R. Weingast, The Political Control of Bureaucracies Under Asymmetric Information, 36 AM. J. PoLI. ScI. 509 (1992) (discussing agency problems arising from politicians attempting to control domestic regulatory bureaucracies, and how politicians can use a combination of administrative procedures and interest group monitoring to mitigate this).

4. Policymakers might care in principle about avoiding the dangers of building power without capacity, but these may be offset by the value of using power to convince (naïve) voters that the government does possess the capacity to deal with transnational threats. The dangers of using power without capacity may be perceived as longer-term threats (if they are perceived as threats at all), and politicians' discount functions may be different from those of voters. The use of power without capacity is a variation on traditional agency problems, since the decision to use power might convey the impression to the public that the nation-state faces imminent danger, which in turn might redound to the benefit of politicians. See, e.g., John R. Oneal \& Anna Lillian Bryan, The Rally 'Round the Flag Effect in U.S. Foreign Policy Crises, 1950-1985, 17 Pol. BeHAvior 379, 394 (1995) (noting that increases in presidential support in a crisis are greatest when a president's response is reported); see also Matthew Purdy \& Lowell Bergman, Unclear Danger: Inside the Lackawanna Terror Case, N.Y. Times, Oct. 12, 2003, at A1 (despite ambiguities in the extent of danger posed by the alleged terrorist cell in Lackawanna, New York, policymakers, including New York's governor, responded to the arrests by claiming that they sent "a very important message: Terrorism is real, and not just in major cities").

5. For a discussion of the difficulties involved in such analysis of costs and benefits, see Mariano-Florentino Cuéllar, Choosing Anti-terror Targets by National Origin and Race, 6 HARV. Latino L. Rev. 9 (2003) [hereinafter Choosing Anti-terror Targets]. 
ruption to terrorism. ${ }^{6}$ I use the term "criminal finance" to refer to financial activity linked in some way to deriving profits from crime, or to funding crime. The global attack on such activity is grounded in the view that many perpetrators of transnational crime are motivated by financial gain-and still others need funds to achieve their illegal objectives. ${ }^{7}$ So perhaps it is not surprising that much of the serious discussion about reducing transnational crime or even national security threats invariably turns to the importance of disentangling money from crime. ${ }^{8}$

Parallel to the rhetoric, many nation-states have instituted legal changes allegedly critical to the success of transnational law enforcement. Legislatures have established separate penalties to punish financial activity that furthers certain predicate crimes. ${ }^{9}$ Law enforcement officials prosecute people who fund or profit from serious predicate crimes. Working with regulators, they freeze as-

6. The global attack on criminal finance is hailed constantly as an integral component of any serious effort against transnational crime. The provisions of the United Nations Convention Against Transnational Organized Crime, G.A. Res. 55/25, annex I, 55 U.N. GAOR Supp. (No. 49) at 44, U.N. Doc. A/45/49 (Vol. I) (2001) (entry into force Sept. 29, 2003), underscore the alleged centrality of the global attack on criminal finance to controlling transnational crime. Article 6 of the Convention provides that states parties shall establish "as criminal offences. . concealment or disguise of the true nature, source, location, disposition, movement or. . property, knowing that such property is the proceeds of crime," and Article 7 requires signatories to "institute a comprehensive domestic regulatory and supervisory regime for banks and non-bank financial institutions and. . other bodies particularly susceptible to money laundering." Other ventures include-among others-airline hijackings, weapons trafficking, human trafficking, drug trafficking, proliferation of weapons of mass destruction, and cybercrime. None of these ventures reflects the explicit ambition and scope of the global attack on criminal finance-to use criminal penalties and regulation and to have an effect across areas of transnational crime.

7. See, e.g., H. Richard Friman \& Peter Andreas, International Relations and the llicit Global Economy, in The Illicit Global Economy and State Power 1, 1-2 (H. Richard Friman \& Peter Andreas eds., 1999). Writing a half-decade ago, they described the extent of illicit financial flows in the following terms and collected a number of relevant sources:

It is estimated that the trafficking in illegal drugs generates as much as $\$ 500$ billion in annual retail sales, a dramatic jump from just a decade ago. The smuggling of illegal immigrants into advanced industrial countries has developed into a multibillion-dollar business with smugglers charging up to $\$ 50,000$ per head. Dumping and illicit trafficking comprise a growing portion of the cross-border trade in toxic waste, a trade conservatively estimated at $30-45$ million tons and $\$ 15$ billion annually. The clandestine global trade in endangered species is estimated at $\$ 10$ billion annually. Illicit arms sales are fueled by the potential for a "nuclear 'yard sale' in the former Soviet Union" and the black market component of the annual $\$ 40-\$ 50$ billion conventional arms trade. There is even a growing illicit transnational trade in human body parts, thanks to modern technologies that make it possible to store and ship high-demand organs such as kidneys, livers, and bone cartilage. Finally, the 'financial reflection' of these and other illicit transactions contribute to wide-scale money laundering, tax evasion, and capital flight.

Id. at 2 .

8. In terms of the importance of the global attack, see, for example, International Cooperation Needed to Combat Money Laundering, Third Committee Told as Debate on Crime, Drugs Continues, Press Release GASSHGC/3635, United Nations, Fifty-Sixth General Assembly, Third Committee, 11th Meeting (October 16, 2001), available at http:/www.un.org/News/Press/docs/ 2001/gashc3635.doc.htm; Guy Stessens, Money Laundering: A New International Law En. FORCEMENT MODEL (2000); Ronald K. Noble \& Court E. Golumbic, A New Anti-Crime Framework for the World: Merging the Objective and Subjective Models for Fighting Money Laundering, 30 N.Y.U.J. INT'L L. \& PoL. 79 (1997-98).

9. See infra Part I.b.i. 
sets. They regulate financial institutions that may come into contact with currency or bank balances gleaned from slave labor or from selling a kilogram of heroin at street price. Government officials support and invoke international treaties on the subject. Led by the United States and its allies among developed economies in Europe, these efforts generate tens of millions of currency transaction reports; ${ }^{10}$ tens of thousands of suspicious activity reports; ${ }^{11}$ thousands of prosecutions, forfeitures, and orders freezing assets; hundreds of regulatory actions; and dozens of international agreements. Advocates of this global attack on criminal finance envision a steady movement over time toward a world where states' legal power to attack criminal finance will meet the technological, organizational and practical demands of mounting the global attack. ${ }^{12}$

While there may be principled reasons to mount a global attack on criminal finance, the reality involves a bewildering array of disconnections between asserted objectives and real-world results. Despite persistent efforts of government officials to equate these laws with the capacity to disrupt criminal finance ${ }^{13}$ the alignment of power and capacity is likely to be evanescent. Interest groups may oppose regulatory policies that build capacity. Some of the offenses that are easiest to detect, like currency reporting violations, are not the most dangerous or problematic ones. International agreements-even when they are backed up by the threat of extraterritorial sanctions-can succeed in forcing some states to make superficial legal changes but not deeper reforms that

10. See 31 U.S.C. $\$ 5313$ (2003) (establishing main currency transaction reporting requirement for domestic financial transactions); 26 U.S.C. $\S 6050 \mathrm{I}(\mathrm{f})(2003)$ (requiring the filing of reports of commercial transactions involving $\$ 10,000$ or more in currency); 31 U.S.C. $\$ 5316$ (2003) (establishing reporting requirement for the movement of currency or monetary instruments totaling $\$ 10,000$ or more into or out of the U.S.); 31 C.F.R. pt. 103.22(a)(1) (2003) (implementing CTR requirement).

11. See Financial Crimes Enforcement Network, The SaR Activity Rev. Trends, Tips AND IsSUES: IsSUE 55 (2003), available at http://fincen.gov/sarreviewsissue5.htm.

12. Throughout this article, I use the term "state" in the sense used in international law, to describe nation-states assumed to possess a measure of sovereignty and recognized as such under international law. I use the terms "transnational law enforcement" to refer to efforts to disrupt crossborder criminal activity using investigations, criminal prosecutions, and regulatory policy.

13. Government officials also insist that previously-existing and new legal authorities to attack criminal finance are building the United States' capacity to detect and disrupt the most troubling kinds of criminal financial activity. See, e.g., Office of Public Affairs, U.S. Department of the Treasury, Testimony of Juan C. Zarate, Deputy Assistant Secretary, Executive Office of Terrorist Financing and Financial Crime, U.S. Department of the Treasury, before the Senate Foreign Relations Committee (March 18, 2003), available at http://www.ustreas.govpress /releases/js139.htm ("Since September 11 th, we have led a global campaign to identify, disrupt, and dismantle the sources and means of funding for Al Qaida and other terrorist groups .... We therefore have attacked the financial infrastructure of terrorist groups and held accountable those who bankroll terror."); see also Office of Public Affairs, U.S. Department of the Treasury, Statement of Jimmy Gurule, Under Secretary for Enforcement, U.S. Department of the Treasury, before the Subcommittee on Treasury, Postal Service, and General Government, Committee on Appropriations (February 28, 2002), available at http://www.ustreas.gov/press/releases/pol057.htm ("Of particular importance to our counter-terrorist efforts is the USA PATRIOT Act that clarifies the law enforcement and intelligence communities' authority to share financial information regarding terrorist investigations. These provisions are already being utilized and are bearing fruit in disrupting financial networks"); see also Anti-Money Laundering Efforts in Texas: Field Hearing Before the Committee on Banking, Finance, and Urban Affairs, House of Representatives, 103rd Cong. 91-92 (Statement of Ronald K. Noble, Treasury Under Secretary for Enforcement). 
could directly affect criminal financial activity but may offend domestic financial interests. In developed countries, executive branch officials with ample power but scarce capacity to pursue the attack on criminal finance may still end up using this "disequilibrated" power to send citizens a signal that in fact they have built the capacity to reduce dreaded threats. Since power is visible and capacity rarely is, law enforcement officials might even trade away capacity in exchange for more power. ${ }^{14}$ Finally, both developed and less developed states may find it difficult to regulate some financial transactions because substitute systems of exchange can be used to achieve them. People who want to avoid heavily-regulated banks can transport currency across borders, or they can seek out a Hawaladar who can informally arrange the transfer, for a price. ${ }^{15}$ All of these forces can help create-and maintain - a gap between a state's legal powers to address citizens' most pressing security concerns and a state's capacity to deploy its draconian legal powers to actually reduce these threats at the margin. While the gap can make some legal actions futile, or even wreak perverse consequences, scholars of transnational law have seldom, if ever, addressed the issue. $^{16}$

The remainder of this article elaborates on the preceding arguments in three parts. Part I explains the global attack on criminal finance. There I discuss the doctrinal structure and justification for this new trend in transnational criminal law. I also explain the justifications for making the attack global rather than merely domestic, and I discuss the proliferation of different criminal and regulatory laws generated by the interest in disrupting criminal finance. Part II then discusses a central problem in the global attack on criminal finance and in transnational law enforcement more generally: the separation between state legal

14. See infra Part II.b.iii. See also Mariano-Florentino Cuéllar, The Tenuous Relationship Between the Fight Against Money Laundering and the Disruption of Criminal Finance, 93 J. CRIM. L. \& Criminology 311, 447-48 (2003) [hereinafter Tenuous Relationship] ("Lawmakers might be less concerned about the details of regulatory implementation designed to target criminal finance, because few among the public are likely to understand the value of it.").

15. See infra Part II.b.iv.

16. What research there is on state power and capacity tends to question whether there has been a decline in state "power" given the rise of non-state actors such as organized criminal networks or multinational corporations. As best I can tell, this literature does not draw any significant distinctions between state legal powers and state capacity to use those powers to achieve desired goals. See, e.g, LouISE I. Shelley, Transnational Organized Crime: The New Authoritarianism, in The Illicit Global Economy and State Power 25, 46 (H. Richard Friman \& Peter Andreas eds., 1999) ("The authoritarianism of transnational organized crime is predicated on a weak state"). Some scholars also draw distinctions between "weak states" and "powerful" states without distinguishing coercive authority, whether or not legitimized by law, from broader capabilities to achieve state objectives. See, e.g., Eric Posner, Do States Have a Moral Obligation to Obey International Law?, 55 STAN. L. REV. 1901, 1915 (2003) ("'M]y argument is confined to the existing international system, where powerful states have more influence than weak states and compliance is rare."); Kal Raustiala, The Architecture of International Cooperation: Transgovernmental Networks and the Future of International Law, 43 VA. J. INT'L L. 1, 67 (2002) ("For weak states the import of regulation can be thought of as 'a price of admission' to the fullest range of benefits provided by the network."); Mortimer Sellers, The Legitimacy of Humanitarian Intervention Under International Law, 7 INT'L LEGAL ThEORY 67, 76 (2001) ("Large powerful states that violate international law do not face the same levels of enforcement that smaller weaker states do. Small weak states can seldom act to prevent human rights violations from occurring elsewhere."). 
power to severely punish offenses and state capacity to detect and target the most important offenders-and the pressing threats-that citizens fear. I develop the argument by surveying various dynamics that create agency problems and tend to separate the extent of legal power used in the global attack on criminal finance from state capacity. Part III considers possible consequences of that separation, which include dilution of political pressures on nation-states to adopt policies that are costly to policymakers but have a greater probability for building capacity, and the creation of pressures that may radicalize actors in a position to exacerbate transnational threats. Nation-states ignoring these risks incur yet another risk: namely, that the gap between power and capacity will render some transnational law enforcement efforts self-defeating.

I.

The Global attack on Criminal Finance as a Case Study in Transnational Law EnForcement

To understand the gap between power and capacity it is helpful to start with some background about the subject of this case study. During the last decades of the twentieth century the United States and some of its allies started assailing the fact that certain people were becoming fabulously wealthy from engaging in cross-border illegal activity, and that money from around the world could be used to fund illegal activity such as terrorism. In the United States, much of this focus on criminal finance arose from legislative and executive responses to political circumstances. ${ }^{17}$ Attacking criminal finance made for compelling symbolic politics amidst growing public concern about drug trafficking, and the attack conveniently provided a means to demonstrate that policymakers were addressing amorphous but increasingly salient global threats. Nonetheless, as I explain below, there is also a principled case to be made for this global attack.

\section{A. Legal Structure of the Attack on Criminal Finance}

Doctrinally, one might envision the attack on criminal finance either of two ways. One approach is to think of a prohibition on "criminal finance" as an expansion in the scope of preexisting, proscribed offenses. Thus, financing terrorism becomes an instance of terrorism, and drug money laundering is just an example of conspiracy to commit a drug offense. ${ }^{18}$ The other approach is to think of criminal finance as a separate offense altogether, where the gravamen of the offense is not its direct relationship to the predicate crime, but rather the act of using knowledge and technical capacity to manipulate the financial system in nefarious ways. Under this conception, criminal finance is more like fraud-involving someone who appears respectable but uses the financial system

17. Elsewhere, I develop a more detailed analysis of the political circumstances affecting the development of anti-money laundering laws, which constitute a major part of the global attack on criminal finance. See Cuéllar, Tenuous Relationship, supra note 14, at 444-50.

18. Indeed, some judicial decisions predating the modern anti-money laundering statutes explicitly recognize how someone who helps solve a drug trafficker's financial challenges should be viewed as a conspirator. See, e.g., United States v. Barnes, 604 F.2d 121, 154-55 (2d Cir. 1979). 
for illegal ends. ${ }^{19}$ Obviously these two conceptions might play out differently in context, but the important lesson for now is that both are certainly compatible with the basic criminal justice framework in play throughout the world.

For example, under either of these conceptions, the state decides to criminalize activity having a presumed connection to inherently harmful conduct that is difficult to observe. Thus a person transacting with a criminal guilty of drug trafficking or corruption and hiding the money's origin is not just punished for the marginal additional harm that the transaction itself creates, but for the unobserved activities presumably connected to the money laundering crime. The implication is that for every suitcase of crumpled bills turned into a credit in a Bahamian bank account, there occurred various drug smuggling and distribution activities, attempts to entice fifteen year-olds into a drug habit, as well as the reinvestment of criminal proceeds in corruption and crime. ${ }^{20}$ Far from being a unique feature of the attack on criminal finance, this sort of "administrative presumption" crime is increasingly common in criminal codes. Drug possession crimes might be understood this way-the punishment being a way of responding not just to the perceived harm of someone holding onto the drugs, but for presumed past and future crimes. Perhaps because many "criminal finance" offenses have this characteristic, the expansion of the global attack has been relatively easy to graft onto existing criminal codes.

The amended criminal codes then allow a turn toward investigating and prosecuting a sort of "indirect liability." Historically, transnational law enforcement concerned itself with willful offenses like piracy, hijackings, and drug trafficking. People were the subject of extradition warrants and international condemnation because they were willing offenders. In contrast, the intent requirement in laws and regulations targeting criminal finance is supposed to be quite low. Instead of only punishing transnational criminals involved in willful activities (i.e., giving money to a front-group for terrorists posing as a charity, where the donor harbors the purpose of funding terrorism), the global attack implies a concern even with those who are merely reckless or negligent. ${ }^{21}$ All of this involves the ascription of responsibility to people who are not directly

19. For an example of this sort of framing, see U.S. Dep't OF THE TREASURY, The National MONEy LaunderING StRategY FOR 20007 (2000) ("Money laundering taints our financial institutions, and, if left unchecked, can undermine public trust in their integrity.").

20. As an analogy, one could try to justify the severe mandatory minimums associated with the simple possession of five grams or more of a substance containing cocaine base as a substitute for proving that someone is involved in drug distribution. See 21 U.S.C. $\$ 844$ (2001) (establishing a five-year mandatory minimum sentence for possession of five or more grams of cocaine base). Of course, this leaves the question of evaluating the purported harm (for example, cocaine distribution), deciding on the sufficiency of the connection between the allegedly harmful activity and the proscribed activity (cocaine base possession), and determining which institution(s) should control the answers to the preceding questions.

21. This unusual trend in transnational criminal law is in full display in a coterie of model laws designed to combat money laundering. For example, the Commonwealth Model Law for the Prohibition of Money Laundering defines the offense in relevant part as follows:

"money laundering" means -

(a)(i) engaging, directly or indirectly, in a transaction that involves property that is proceeds of crime: or 
committing the underlying predicate offense. Individuals must increasingly shoulder the burden of assuring that, say, a charity to whom they would like to contribute is not itself contributing to another organization that is engaged in terrorist activity. Indirect liability is then supplemented with regulation and civil penalties. The more dangerous a particular criminal offense is considered, the easier it is for legislators and executive branch officials to make a case for regulatory requirements to supplement the bare criminal statutes defining an offense. Regulation is powerful stuff: it allows the state to use numerous civil penalties against people who engage in prohibited conduct but who are not worth subjecting to criminal punishments.

This brings us to the role of the financial system. Supporters of the global attack imply that the financial system should be used as a lever to combat crime. Conversely, they believe the financial system should not itself be used to facilitate-even incidentally - the activities of criminals. Just as environmental or occupational safety regulation is meant to reduce the risk of some harms, so is regulation of the financial system used to reduce a compound risk: that financial institutions will be used to make it easier to finance and profit from crime, and that such financial activity will actually result in a marginal increase in offending rates. ${ }^{22}$ Through regulatory requirements, officials can impose liability on banks and financial institutions even when it is neither possible nor desirable to resort to imposing criminal liability. The regulatory requirements may also generate information, which can be useful in at least three different interrelated ways. The most obvious payoff to using financial information against crime is in the prosecution or the final stages of an investigation of a suspect. A prosecutor anywhere from Baltimore to Basle to the Bahamas can use financial records to establish a defendant's motive. Wire transfer records also help establish the relationship between associates. Finally, financial records can impeach a witness or bolster her credibility. In short, financial records are evidence, and thus in a capable prosecutor's hands, they help achieve punishment in a legal system that requires proof.

(ii) receiving, possessing, concealing, disguising, transferring, converting, disposing of, removing from or bringing into the (territory) any property that is proceeds of crime; and

(b)(i) knowing, or having reasonable grounds for suspecting that the property is derived or realised, directly or indirectly, from some form of unlawful activity.

Commonwealth Model Law for the Prohibition of Money Laundering (2003), available at http:// www.imolin.org/Comsecml.pdf. This means that a person who "indirectly" engages in a transaction involving property that is the proceeds of crime, and has "reasonable grounds for suspecting" that the property is derived from unlawful activity would be guilty. This negligence standard comports with that found in another model law, the Model Money-Laundering, Proceeds of Crime and Terrorist Financing Bill Part II, 17 (2003), available at http://www.imolin.org/ poctf03.htm. That document provides that: "A person commits the offence of money-laundering if the person . . . acquires, possesses or uses property, knowing or having reason to believe that it is derived directly or indirectly from acts or omissions."

22. As with environmental or occupational regulation, the use of regulation in this context raises questions about transnational enforcement. Regulated parties may substitute activities that take place in less-regulated jurisdictions. See infra Part II.b.iv. 
Yet the turn to the financial system also represents a grander ambition still: to churn through information and sort transactions into more and less suspicious ones, thereby helping people in charge of enforcing the law decide how to allocate their scarce investigative resources. Virtually all law enforcement activity involves some sifting through information to decide on potential threats to target. Even a cop walking down the street uses his physical senses to carry out some version of this. ${ }^{23}$ One may rightly question whether harvesting such information would dramatically expand states' ability to punish transnational crime. The only point to emphasize here is that the motivation behind attacking criminal finance is to exploit the possibility that financial information can have substantial law enforcement payoffs. The record of such activity may be mixed, particularly given the likely resistance from financial groups, but the ambition is still central to understanding the attack on criminal finance.

The regulations are supposed to work with the criminal laws to disrupt criminal finance. In other work, I elaborate on the justifications for targeting not only money laundering, but criminal finance more generally. ${ }^{24}$ Two things are worth emphasizing here. First, it is certainly possible to make a plausible, utilitarian argument for targeting criminal finance. The argument does not imply that targeting criminal finance is the only or even the best way of reducing illicit activity. Instead, the point is that if we make a few plausible assumptions, it makes sense to disrupt criminal finance as part of a larger strategy to target illicit activity. Second, the plausible justification for attacking criminal finance can also justify an international or global attack.

With respect to the first point, money matters because people tend to respond to costs and benefits, and these are often easily measured in money. ${ }^{25}$ For example, drug traffickers, human traffickers, and terrorists must all solve organizational problems. Many of those problems can be solved with money. But the irony is that money creates as well as solves organizational problems. If it is in cash, then it must be deposited and moved. Even if it is not in cash, money must still be managed, raised, and directed towards particular activities. It must be guarded from people who would rather convert it to personal use. Its origins (or in some cases even its existence) must be kept secret from governments. In principle, the lower the cost of solving the organizational problems

23. I have written at length about the prospects for sorting through such information. See Cuéllar, Tenuous Relationship, supra note 14, at 444-47.

24. Id. at 380 .

25. For a thorough review of equilibrium models of crime consistent with this notion, see Isaac Ehrlich, Crime, Punishment, and the Market for Offenses, 10 J. Econ. Persp. 43, 46 (1996). Thus:

A person's decision to participate in illegal activity $i$ can be viewed as motivated by the costs and gains from such activity. These include the expected illegitimate payoff (loot) per offense, $w_{i}$; the direct costs incurred by offenders in acquiring the loot (including the costs of self-protection to escape punishment), $c_{i}$; the wage rate in an alternative legitimate activity, $w_{i}$; the probability of apprehension and conviction, $p_{i}$; the prospective penalty if convicted, $f_{i}$, and finally one's taste (or distaste) for crime a combination of moral values, proclivity for violence, and preference for risk.

Id. at 46. See also Peter Reuter, Robert MacCoun, \& Patrick Murphy, Money from Crime: A Study of the Economics of Drug Dealing in Washington, D.C., RAND Corporation Report (1990). 
associated with money, the easier it is to commit numerous offenses that require, generate, or benefit from money. This makes offenders have a sort of love-hate relationship with the legitimate financial system, which encompasses private and commercial banks, investment banks and broker dealers, commodities traders, and businesses selling legitimate goods and services. While cash combines the blessing of anonymity along with the complication of bulk, the legitimate financial system does exactly the opposite. On the one hand, the financial system can collect information and therefore establish a proverbial paper trail to trace transactions. On the other hand, the financial system has largely evolved from economic and political pressures that have forced it to be very good at solving organizational problems involving money-including how to store it, move it, guard it, and reinvest it at an adequate rate of return. ${ }^{26}$

To illustrate the potential payoffs of the global attack, suppose we are trying to understand the impact of financial anonymity on the extent of illegal activity. A large number of offenders should crave the cloak of anonymity: the greater the financial anonymity they have, the more they might be willing to participate in financing and supporting illegal activity. ${ }^{27}$ The figure below illustrates the relationship between crime and financial anonymity posited by proponents of the global attack. One axis is financial anonymity. The other tracks the product of the quantity and severity of illegal activity demanded by some group or individual. The lines $\mathrm{L} 1$ and $\mathrm{L} 2$ represent two alternative government-imposed limits on anonymity (that is, achieved through criminal penalties and investigative strategies, regulations, or international agreements limiting bank secrecy). In the diagram, moving from $\mathrm{L} 2$ to $\mathrm{L} 1$ may be expensive for the government, but lowers the illegal activity demanded from I* to Iq. The precise impact of the reduction depends on the slope of the line connecting the extent of financial anonymity to the illegal activity demanded. Thus, curve $S$ represents one function, while curve $S$ ' illustrates how reductions in financial anonymity may have a milder impact on illegal activity where offenders are less concerned about being caught. ${ }^{28}$

Of course, people whose interest in crime is partly driven by profit may not always react in ways that could be easily described as "rational." 29 However, one may care about anonymity without conforming to a more elaborate defini-

26. See generally Cuéllar, Tenuous Relationship, supra note 14, at 382.

27. Anonymity may entice potential offenders to think they will be able to spend their illicit gains without facing added risk of being punished. Some people who finance or profit from offenses are likely to value things that are endangered by the absence of anonymity, including (among other things) some combination of the following: freedom to lead a life that appears to be tied to legitimate economic pursuits, freedom from detection by law enforcement, flexibility to solve organizational and financial problems without incurring added risks of detection, or lack of attention from other people involved in illicit activities.

28. Curve $S$ is concave to capture the possibility that certain offenders would only find it enticing to finance crime if there is virtually no possibility of being detected. Different assumptions would yield a different curve.

29. A particularly thoughtful account of some of the non-financial incentives enticing potential criminals is Jack Katz, Seductions of Crime: Moral and Sensual Attractions in Doing EviL (1988). But note that this account, which emphasizes the non-financial attractions of crime, focuses on illicit activities with relatively low financial returns. 


\section{Impact of Financial Anonymity on Illegal Activity (Other Things Being Equal)}

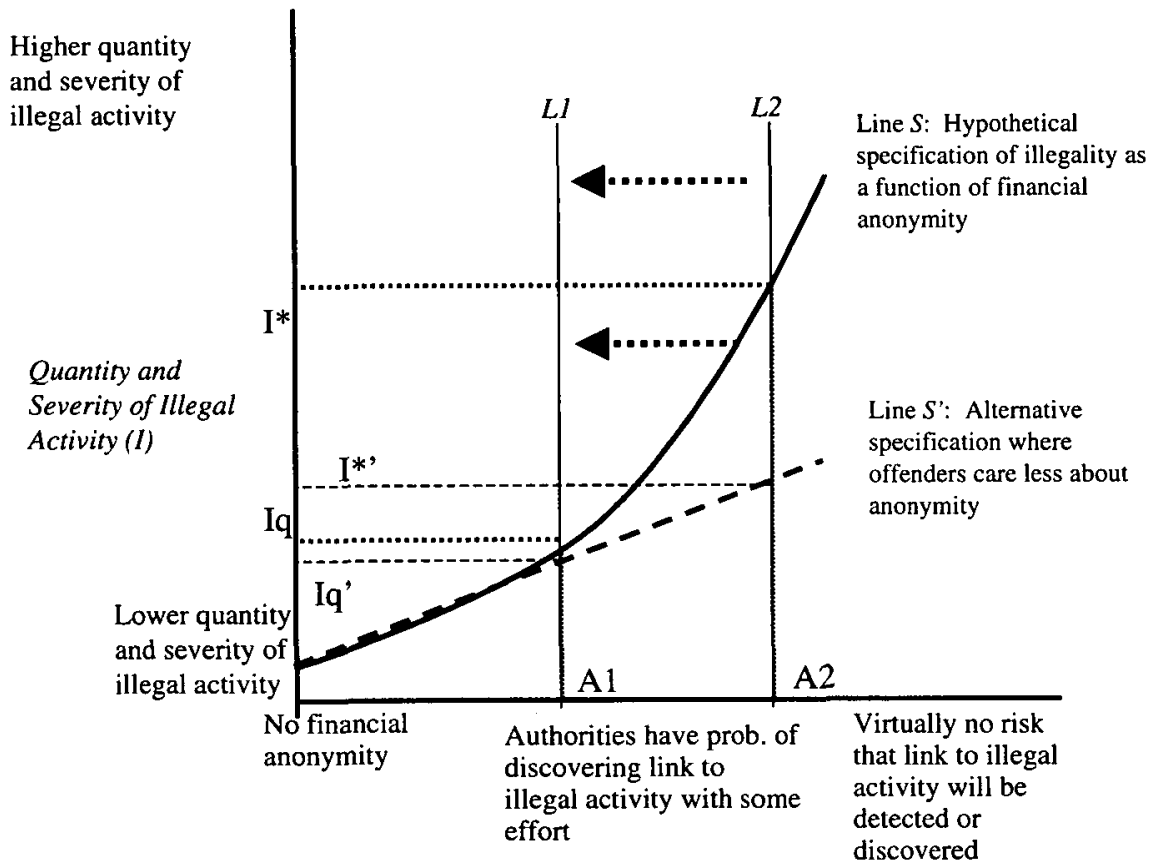

Financial Anonymity (A)

tion of instrumental rationality: even terrorists who believe they have a date with destiny want to avoid being foiled before they execute their plan, and many other serious offenders, when given a choice, would rather avoid detection than attract attention. ${ }^{30}$ This means that lines like $S$ and $S$ ' should be expected to slope upward. The precise usefulness of targeting criminal finance then depends on the aggregate slope of line $\mathrm{S}$, as well as a few other reasonable assumptions, like postulating that the government can move the limit on anonymity from L2 to $\mathrm{Ll}$ at a reasonable cost. ${ }^{31}$

Notice that some of the justification for the global attack would still apply even if there were imperfections in the detection system used to identify targeted accounts. Nowhere does the law ever claim (or perhaps even aspire to) perfection, even when a convicted felon's life is at stake. Sometimes it is hard to

30. See Cuéllar, Tenuous Relationship, supra note 14, at 386 (". . .even individuals whose desire to engage in terrorist activity could hardly be termed 'rational' might still make reasoned judgments meant to maximize the success of their activity and lower the risk of detection.").

31. Note that even if individual supply-of-offense functions were completely inelastic with respect to variations in financial anonymity above some critical threshold level, the whole population might still exhibit an elastic curve indicating the supply of offenses relative to financial anonymity. As long as changes in the degree of financial anonymity actually changed the return from offenses, then the return from criminal activity would change for marginal offenders, thus inducing them to engage in (or refrain from) illegal activity. 
know if someone is genuinely guilty of an offense, and other times the underlying substantive offenses themselves are hardly more than prophylactic measures against people who may not ultimately be engaging in the most dreaded harm. When it comes to the global attack on criminal finance, we might imagine that if people knew some economic activities created the appearance of impropriety, then people could assiduously avoid these activities (such as, transactions with particular people, organizations, or countries). This would be fine if we believed that, among other things, there is sufficiently low social value in the suspect activity that we would not mind deterring it, and that firms taking steps to avoid impropriety will recognize they are being rewarded. Things start to get more problematic if the capacity to detect troubling financial transactions is extremely low, a point to which I return below. ${ }^{32}$

\section{B. The Role of Treaties and Extraterritorial Power}

Because crimes occur across the rivers and barbed wire fences that separate nation-states, one can also imagine some plausible reasons for policymakers in one country to be concerned about criminal finance around the globe. The United States and its allies have built a system of international agreements, multilateral conventions, and United Nations resolutions that call on countries (and in some cases establish mild requirements) to join the global attack on criminal finance. The threat or use of extraterritorial legal authority has also become a regular part of the global attack. Nonetheless, despite the noise made about these strategies, their impact is limited by problems involving the detection of offenses and the monitoring of countries implementing legal changes.

\section{Justifications for Making the Attack Global}

People easily can make cross-border financial transactions given a combination of financial technology and international agreements that have resulted from decades of efforts to facilitate cross-border financial transactions. ${ }^{33}$ Transnational wire transfers are simple to execute. ${ }^{34}$ Just as currency traders in the United States can purchase local currency in Brazil with little effort, so too can weapons brokers execute transactions to buy surplus Iranian machine guns and pay for them with money from a Swiss bank account. If authorities in one state

32. See infra Part III (explaining the political dynamic that might have a perverse effect on Islamic charities and others who are subject to power but may not be saved by a capacity focus).

33. Between the mid-1980s and mid-1990s, daily foreign exchange transactions increased by a factor of 6.5 to $\$ 1.3$ trillion. Thomas D. Lairson \& David Skidmore, InTERnational Political Economy: The Struggle for Power and Wealth 102 (1997). For a useful discussion of the mechanics of wire transfers, see Raj Bhala, Paying for the Deal: An Analysis of Wire Transfer Law and International Market Interest Groups, 42 U. KAN. L. REv. 667 (1994).

34. The combination of international migration and simple means of making transfers among financial accounts has fueled a massive volume of financial remittances flowing from developed economies to less-developed countries. See Richard H. Adams, International Migration, Remittances and the Brain Drain: A Study of 24 Labor-Exporting Countries (World Bank Policy Research, Working Paper No. 3069, 2003), available at http:/econ.worldbank.org/files/ 27217_wps3069.pdf. Criminal financial transactions thus become needles in vast haystacks of remittance-related transactions. 
decided to invest in a comprehensive regulatory and criminal enforcement program to disrupt criminal finance, offenders might try to evade its consequences by shifting their financial resources to a jurisdiction that either did not collaborate in the global attack on criminal finance or tried to collaborate but did not do so well. Indeed, some jurisdictions might be even more desirable to offenders because of strong laws protecting bank secrecy. ${ }^{35}$ Part of this might be remedied in the United States by implementing controls on cross-border movements of financial resources. This already happens to some extent. ${ }^{36}$ But given the competing interest of maintaining relative freedom of movement of capital across borders, money moves easily into and out of the United States, and most reporting requirements only focus on a tiny fraction of this flow. ${ }^{37}$ Unless one believed (implausibly) that the legal regulation of financial flows into and out of the United States intercepted the bulk of transactions connected to criminal finance, it would seem necessary to think about extending the attack on criminal finance to other jurisdictions.

In many cases, the cross-border aspect of criminal activities also generates added enforcement costs. Law enforcement bureaucracies sometimes have a difficult time sharing information and coordinating their efforts. ${ }^{38}$ Investigators and law enforcement officials from different countries may not trust each other. ${ }^{39}$ They may not even have a clue that both are trying to nail the same narcotics smuggler. Countries tend to restrict foreign agents' rights to operate. ${ }^{40}$ Countries differ in their success regulating corruption and the informal sector,

35. See generally Mark Hampton: The Offshore Interface: Tax Havens in the Global Economy (1996) (discussing different degrees of secrecy provided by various jurisdictions, and distinguishing between tax havens and bank secrecy havens).

36. See, e.g., 31 U.S.C. $\$ 5316$ (2003) (establishing currency reporting requirement for movements of currency or monetary instruments in the amount of $\$ 10,000$ or more across the border).

37. See Cuellar, Tenuous Relationship, supra note 14, at 441.

38. See Egmont Group, FIU's in Action (100 Santized Cases from the Egmont Group) 100 (2000), available at http://www.fincen.gov/fiuinaction.pdf (October 24, 2003); see, e.g., Lester M. Joseph, Money Laundering Enforcement: Following the Money, 6 Econ. Perspectives: AN Electronic Journal of the U.S. Department of State (May 2001), available at http://usinfo. state.gov/journals/ites/0501/ijee/justice.htm. Joseph, a Justice Department official, notes:

[D] ue to the existence of offshore banks with representative offices in other foreign countries, U.S. law enforcement officials often encounter difficulty trying to determine the actual location of the funds and in which jurisdiction to focus forfeiture efforts. ... One response to this is that states try to make such information sharing and joint investigations easier. But they have not reduced the cost enough to eliminate its impact on scarce enforcement resources. Even where U.S. law enforcement requests the assistance of the correct foreign jurisdiction, our ability to forfeit these funds depends upon the strength of forfeiture laws in that jurisdiction, which, if available, are frequently incompatible with U.S. law, and upon the cooperation of the foreign government.

39. For example, American law enforcement officials sometimes choose to assume the added complication of executing transnational law enforcement operations in foreign soil without obtaining approval from the foreign government instead of divulging the details of the operation. See, e.g., Julia Preston, Mexicans Belittle Drug-Money Sting, N.Y. Times, May 20, 1998, at A6. For a description of one such operation, see U.S. v. Banco Internacional/Bital S.A., 110 F. Supp. 2d 1272 (C.D. Cal. 2000).

40. See Cuéllar, Tenuous Relationship, supra note 14, at 331 n.70 (discussing Mexican laws placing restrictions on foreign law enforcement agents operating in Mexico). 
which allows criminals to leverage their manipulation of businesses or law enforcement in one country to engage in illicit activity in another. ${ }^{41}$ This means that whenever offenders succeed in introducing a layer of international transactions, they effectively move the degree of "financial anonymity" along the horizontal dimension depicted in the figure above. It is hard to see how this added enforcement cost generated by cross-border transactions could ever be completely extinguished. Nonetheless, extending the global attack to other countries could have a marginal impact: two countries that both have anti-money laundering investigators and gather information about suspicious transactions may find it easier to detect and prosecute an offender than two countries where only one makes any effort to target criminal finance.

This is more than speculation. For example, some offenders use bank secrecy havens, such as those in Panama and the Cayman Islands, to scatter money to multiple accounts. Correspondent bank accounts involve a loosely regulated financial institution-such as an offshore shell bank-providing customers with banking services in a more highly regulated jurisdiction (like the United States) ${ }^{42}$ The shell bank establishes an account at a full-service United States bank, which makes it easy for the shell bank's customer (or owner) to take advantage of the financial structure of the more highly-regulated bank. ${ }^{43}$ Over the years, established banks have struck up correspondent relationships with large numbers of offshore banks, as chronicled by the staff report of one Senate Subcommittee:

The industry norm today is for U.S. banks to have dozens, hundreds, or even thousands of correspondent relationships, including a number of relationships with high-risk foreign banks. Virtually every U.S. bank examined by the Minority Staff investigation had accounts with offshore banks, and some had relationships with shell banks with no physical presence in any jurisdiction. High-risk foreign banks have been able to open correspondent accounts at U.S. banks and conduct their operations through their U.S. accounts, because, in many cases, U.S. banks fail to adequately screen and monitor foreign banks as clients. ${ }^{44}$

41. Suppose a person is trying to move money away from the United States to hide its link to illicit activity. He may want to use sham companies, which may be easier to create and control in foreign jurisdictions. Then he can use the companies as a front to open foreign bank accounts that can send or receive wire transfers. See, e.g., United States v. Hurley, 957 F.2d 1 (1st Cir. 1992) (lawyers involved in drug smuggling and money laundering set up "several Panamanian and Bahamian companies. . ." to facilitate laundering, but "[n]one of the public records reveal" their ownership).

42. The term "offshore bank" is often used to describe banks whose licenses do not allow them to engage in transactions with the citizens of their own licensing jurisdictions, or limit them from transacting business using the local currency. See Role of U.S. Correspondent Banking in International Money Laundering: Hearing Before the Permanent Subcommittee on Investigations of the Senate Comm. on Governmental Affairs, 107th Cong. 278 n.3 (2001) (Minority Staff Report on Correspondent Banking: A Gateway for Money Laundering) [hereinafter Senate Correspondent Banking Report].

43. The USA PATRIOT Act increased Treasury's regulatory authority to deal with correspondent bank accounts for "offshore shell banks." See Uniting and Strengthening America by Providing Appropriate Tools Required to Intercept and Obstruct Terrorism Act of 2001 (USA PATRIOT Act), Pub. L. No. 107- 56, $\$ 312$ (Oct. 26, 2001) [hereinafter USA PATRIOT Act]. Offshore banks complying with the rules can still take advantage of correspondent banking.

44. See Senate Correspondent Banking Report, supra note 42. The report continues: 
Regardless of the extent of globalization in financial markets, the argument for mounting a global attack on criminal finance still depends to some extent on other things being equal. Policymakers have to trade off costs, benefits, and risks. The point of the global attack would be lost if it were too expensive, too threatening to other social values, or too cumbersome to administer. It would make little sense to shut down or heavily tax valuable cross-border financial flows to make the global attack succeed. Moreover, not every enforcement problem is exclusively (or even primarily) about criminal finance.

Yet nearly every transnational enforcement problem involves the movement of money, often across borders. Terrorists need funds to buy weapons and make bombs. Smugglers need money to pay off customs and immigration inspectors. Weapons traffickers need to raise interim financing. The financial system produces information useful in ex ante and ex post enforcement. And financial anonymity makes it possible for people to support offenses at arm'slength, insulating themselves (or trying to) from the consequences of what they do. Finally, many alternative enforcement strategies-such as hiring more undercover agents, paying off more informants, or detaining immigrants who seem to know something about terrorism-have their own drawbacks. All of this means it would be wrong to dismiss the justification for the global attack as either tunnel vision or unprincipled symbolic politics. ${ }^{45}$ The question is how to implement the attack across borders.

\section{International Agreements}

At least in theory, the United States and its allies have put great stock in the global attack on criminal finance. ${ }^{46}$ The result is a system of international agreements, multilateral conventions, and UN resolutions that call on countries (and in some cases establish mild requirements) to join the global attack on criminal finance. Broadly speaking, international law efforts against criminal finance fall into two categories: the use of formal treaties and the use of international organizations and informal agreements.

The most notable formal treaty dealing with money laundering is the Vienna Convention on Narcotics. ${ }^{47}$ Opened for signature at the height of the

The prevailing principle among U.S. banks has been that any bank holding a valid license issued by a foreign jurisdiction qualifies for a correspondent account, because U.S. banks should be able to rely on the foreign banking license as proof of the foreign bank's good standing. U.S. banks have too often failed to conduct careful due diligence reviews of their foreign bank clients, including obtaining information on the foreign bank's management, finances, reputation, regulatory environment, and antimoney laundering efforts. The frequency of U.S. correspondent relationships with high risk banks. . . belie banking industry assertions that existing policies and practices are sufficient to prevent money laundering in the correspondent banking field.

45. A lot of criminal justice and even national security policy is grounded in conjecture. The global attack on criminal finance is no different. Nonetheless, it is a separate question whether there is at least a plausible theory for why a particular approach to regulating illicit conduct might be fruitful.

46. See supra note 8.

47. United Nations Convention Against Illicit Traffic in Narcotic Drugs and Psychotropic Substances, Dec. 19, 1988, U.N. Doc. E/CONF. 82/15. 
American fixation with drug smuggling and crackdown in the 1980s, the Vienna Convention's main purpose was to prod countries to directly target narcotics trafficking through prosecution, extradition, and new criminal statutes. As such, the Convention was a vehicle to extend the scope of enforcement activity thought to be essential to combat drug trafficking. For example, states signing onto the Convention even committed to passing laws against the possession of equipment useful in drug cultivation. ${ }^{48}$ In this vein, some of the Convention's provisions also commit signatories to criminalize the laundering of drug proceeds. The Convention also calls on countries to pass laws allowing authorities to forfeit property connected to drug trafficking.

Multilateral responses to terrorism evince the same approach of expanding the scope of offenses to include their nexus to financial activity. Shortly after September 11, 2001, the United Nations Security Council passed a resolution requesting that members cooperate in the fight against terrorist financing, ${ }^{49}$ and urged them to ratify the Convention for the Suppression of Terrorist Financing. The Convention, in turn, requires countries to criminalize the financing of terrorism and to establish mechanisms allowing authorities to freeze the assets of charities, businesses, and individuals believed to be financing terrorism. ${ }^{50}$ The focus on broad categories of offenses continues in the current efforts to negotiate regional and broader multilateral treaties on corruption, ${ }^{51}$ and with efforts to establish international legal prohibitions on the sale of "conflict" diamonds gleaned from war zones. ${ }^{52}$ If there is some legacy to these treaties, it does not appear to be in a direct, measurable impact on regulatory policy. Instead the treaties appear to advance a particular normative view of what conduct should be considered an integral component of the underlying offense, and what it takes to combat it. ${ }^{53}$

In contrast, the work of the Financial Action Task Force (FATF) does not depend on formal, binding multilateral agreements. Working under the auspices of the Organization for Economic Cooperation and Development, the FATF promulgates standards and engages in more detailed reviews of the laws and

48. Id. at Article 3(c)(ii).

49. See Security Council Unanimously Adopts Wide-Ranging Anti-Terrorism Resolution; Calls for Suppressing Financing, Improving International Cooperation, United Nations Security Council, Press Release SC/7158, Sept. 28, 2001, available at http://www.un.orgNews/Press /docs/2001/ sc7158.doc.htm.

50. See International Convention for the Suppression of the Financing of Terrorism, December 9, 1999, 39 I.L.M. 270 (2000) (entered into force Apr. 10, 2002).

51. See, e.g., Inter-American Convention Against Corruption, June 27, 1996, S. Treaty Doc. No. 105-39 (1998) (ratified by the Senate, July 27, 2000); Criminal Law Convention on Corruption, Europ. T.S. No. 173, (Jan. 27, 1999), available at http://www.conventions.coe.int/treaty/en/Treaties/ Html/173.htm.

52. For a description of recent efforts to restrict trade in uncertified diamonds, see Tracey Michelle Price, The Kimberley Process: Conflict Diamonds, WTO Obligations, and the Universality Debate, 12 Minn. J. GLob. Tr. 1 (2003).

53. This sort of logic helps build the continuing case that vicarious offenders involved in financial activity that furthers transnational crime should be subject to liability for it. For example, if exploiting national resources during a military conflict is a war crime, then willfully profiting from such exploitation also may be. 
policies that countries use to target criminal finance. ${ }^{54}$ The FATF works on the basis of informal agreements and mutual evaluations of members. In the last few years, the FATF has developed a sort of blacklist of countries that are not considered to be cooperating in the attack on criminal finance. As a result, many smaller jurisdictions like the Bahamas and even the Cayman Islands are passing anti-money laundering laws and regulations. FATF members and nonmembers are trying to adopt its recommendations to combat terrorist financing. All of this is being achieved with minimal use of that traditional staple of public international law, the multilateral treaty. Instead, political pressure, perhaps coupled with the symbolic value of supporting the attack, ${ }^{55}$ has led countries to adopt the FATF's recommendations. ${ }^{56}$

\section{Extraterritorial Power}

Countries seem to extol the expressive function of multilateral approaches, but in practice they rarely use multilateral treaties to advance specific investigations. Even agreements and resolutions with legal force (like the recent United Nations resolutions) leave countries with ample room for discretion. ${ }^{57}$ Instead there is growing extraterritorial use or threat of use of domestic legal authority to achieve international enforcement objectives. ${ }^{58}$ Policymakers in states with a substantial interest in targeting criminal finance have enough incentives to pursue this interest without agreements. ${ }^{59}$ Those governments that are reluctant converts to the global attack have room to adopt legal agreements and pass laws while engaging in a strategy of diluted enforcement. ${ }^{60}$ In the short run, international agreements are likely to have a greater impact if they are backed up by the threat that powerful nation-states will use extraterritorial regulatory authority to

54. See generally Sean D. Murphy, Multilateral Listing of States as Money-Laundering Havens, 94 AM. J. INT'L L. 695 (2000).

55. For a useful survey of the institutional sociology literature and a discussion of its application to transnational law, see Ryan Goodman \& Derek Jinks, Toward an Institutional Theory of Sovereignty, 55 Stan. L. REv. 1749, 1758 (2003). See generally W. Richard ScotT, Institutions AND ORganizations (2001).

56. See Cuéllar, Tenuous Relationship, supra note 14, at 374-76.

57. Id. at 438 .

58. By "extraterritoriality" I mean simply that some legal action undertaken by the government has a direct and substantial effect outside the territory of the United States. This definition encompasses legal actions that have an effect outside U.S. territory through the regulation of some domestic activity. Thus, for example, imposing special measures against a nation-state under Title III of the USA PATRIOT Act may not be an "extraterritorial" action in technical legal terms, because the U.S. government is just prohibiting certain actions on its own territory. Nonetheless, the impact of the special measures have an effect beyond U.S. territory, where financial institutions in the targeted nation-state will be restricted in the scope of their access to the U.S. financial sector.

59. See Cuéllar, Tenuous Relationship, supra note 14, at 390, 440-44; see also infra Appendix. Moreover, domestic financial institutions facing administrative and regulatory costs from the domestic global attack may sometimes support the extension of such cost to competitors located beyond the territory of the state mounting the attack.

60. See Cuellar, Tenuous Relationship, supra note 14, at 440 (noting that the costs of adopting laws advancing the attack on criminal finance are lower when countries can dilute implementation in accordance with domestic political pressures). 
punish countries that do not comply. ${ }^{61}$ The multilateral approach then helps justify coercion related to the pursuit of the global attack where powerful states already have an objective in mind, such as freezing the assets of a specific alleged perpetrator. ${ }^{62}$

The United States has aggressively pursued extraterritorial enforcement. While lawyers and judges accept that some international law crimes should be subject to universal jurisdiction, ${ }^{63}$ American efforts to target transnational crime and promote national security have resulted in a parallel development: the expansion of extraterritorial jurisdiction. Perhaps some lawyers, judges, and policymakers have been persuaded by the idea that the world is increasingly interdependent, a view that strengthens both the move towards increased universal jurisdiction and greater extraterritorial jurisdiction. ${ }^{64}$ Or it may be that countries with more traditional claims of jurisdiction linked to territory fail to please the rest of the world in how they handle their enforcement responsibilities. Whatever the precise cause, the effect is to make it easier for prosecutors and executive branch authorities to convince domestic courts that they should take jurisdiction over an offender whose conduct or person is somewhere else in the world. Although courts occasionally articulate balancing tests to establish whether laws should be given extraterritorial effect, ${ }^{65}$ for the most part they go along with the executive branch's efforts to give extraterritorial effect to United

61. Cf. Stephen R. Krasner, Sovereignty: Organized Hypocrisy 124 (1999) ("Between 1970 and 1990 the United States imposed sanctions against more than a dozen countries for human rights violations.").

62. International law norms can also have an effect on domestic practices without coercion, through various kinds of persuasion or long-term changes in domestic preferences. But these mechanisms would be unlikely to register substantial impact on intensely reluctant states in the short run.

63. See Peterson v. Islamic Republic of Iran, No. Civ.A.01-2094, 2003 WL 21251867, at*10 (D.D.C. May 30, 2003) (holding that 28 U.S.C. $\$ 1605(a)(7)$ provides for personal jurisdiction over foreign state sponsors of terrorism); Presbyterian Church of Sudan v. Talisman Energy, Inc., 244 F. Supp. 2d 289, 306 (S.D.N.Y. 2003) ("[S]tates may exercise universal jurisdiction over acts committed in violation of jus cogens norms. This universal jurisdiction extends not merely to criminal liability but may also extend to civil liability."); Flatow v. Islamic Republic of Iran, 999 F.Supp. 1, 14 (D.D.C. 1998) ("As international terrorism is subject to universal jurisdiction, Defendants had adequate notice that their actions were wrongful and susceptible to adjudication in the United States."). But see U.S. v. Yousef, 327 F.3d 56 (2d Cir. 2003) (holding that terrorism is not subject to universal jurisdiction).

64. Cf. United States v. Nippon Paper Industries, 109 F.3d 1, 12 (1st Cir. 1997) (Lynch, J., concurring) (extraterritorial application of criminal provisions in the Sherman Antitrust Act are "reasonable," because "raising the prices in the United States and Canada was not only a purpose of the alleged conspiracy, it was the purpose. ..").

65. See, e.g., Steele v. Bulova Watch Co., 73 S.Ct. 252 (1952) ("[T]he legislation of Congress will not extend beyond the boundaries of the United States unless a contrary legislative intent appears."). 
States laws. ${ }^{66}$ The United States therefore has come to routinely apply extraterritorial jurisdiction. ${ }^{67}$ Other countries may cautiously follow.

Some of this is understandable. From the start, some states were big supporters of the global attack but were also committed to a financial architecture built on the relatively free movement of capital. They were trying to have their cake and eat it, too. This pushed the global attack towards reliance on domestic law instead of macro-level controls on financial flows connected to illegal activity. ${ }^{68}$ In recent years, some governments have moved away from this position and acknowledged that the global attack will sometimes disrupt legitimate financial flows. Yet much of the global attack is still carried out through domestic laws rather than elaborate international legal mechanisms used for trade or multilateral sovereign lending. Moreover, to the extent that states $d o$ rely on public international law, by itself it is not likely to deliver what the major sponsors of the global attack claim to want, which is to directly impact the amount of criminal financial activity. Even when international measures help establish a global norm (maybe even enough for some to argue that a new customary international law rule has developed), there are limits to what we can expect from international agreements. ${ }^{69}$ For example, international agreements and FATF recommendations may create a dynamic where legal changes occur on the surface, but enough discretion remains to avoid strict enforcement. ${ }^{70}$

Extraterritorial application of domestic law, however, has the potential for more direct effects. The United States and other governments can thus rely on cross-border criminal prosecutions, the threat of special measures that could be

66.' See, e.g., 18 U.S.C.A. § 175 (2003) (granting extraterritorial jurisdiction to the federal government for certain crimes relating to biological weapons); 18 U.S.C.A. $\$ 351,1751$ (2003) (granting extraterritorial jurisdiction for assassination of certain high level government officials); 18 U.S.C.A. $\$ \S 1512-13$ (2003) (granting extraterritorial jurisdiction for certain crimes against a witness, victim, or informant); 18 U.S.C.A. $\$ \$ 2339 B(d)$ (2001) (granting extraterritorial federal jurisdiction to providing material support or resources to designated terrorist organizations).

67. See, e.g., Anne-Marie Slaughter \& David T. Zaring, Extraterritoriality in a Global.IZED World 23 (Social Science Research Network, Working Paper, 1997), available at http://papers.ssrn.com/sol3/delivery.cfm /9706231.pdf?abstractid=39380 ("U.S. courts have applied U.S. criminal statutes abroad in a variety of contexts"); see also M. Sornarajah, Extraterritorial Criminal Jurisdiction: British, American, and Commonwealth Perspectives, 2 SING. J. INT'L \& Cомp. L. 1, 36-37 (1998) (reviewing cases and finding increasing movement in the United States, the United Kingdom, and the Commonwealth Countries towards the recognition of extraterritorial jurisdiction over drug trafficking and related offenses, and-to a somewhat lesser degree-over fraud offenses).

68. See Eric Helleiner, State Power and the Regulation of Illicit Activity in Global Finance, in The Illicit Global. Economy and State Power 66 (H. Richard Friman \& Peter Andreas eds., 1999) ("Instead of controlling money laundering at borders, the anti-money laundering regime seeks to bolster the ability of governments to crack down on money laundering domestically.").

69. See, e.g., KRASNER, supra note 61, at 31-32 (noting that "enforcement and monitoring mechanisms for [international] conventions vary enormously," and that the question of whether ... conventions alter policy can only be answered by examining behavior, not simply by looking at the terms of the agreement.")

70. See Cuéllar, Tenuous Relationship, supra note 14, at 438; cf. KRASNER, supra note 61, at 32 ("Where enforcement and monitoring provisions have been weak, as has generally been the case for human rights regimes, rulers might sign because, even though they are indifferent or antipathetic. . they might believe that signing would make their regime appear more palatable to external or internal actors."). 
used against countries that do not participate, and discretionary national security powers given by statutes like the International Emergency Economic Powers Act (IEEPA) ${ }^{71}$ Credible threats to use measures under the PATRIOT Act and other extraterritorial regulatory measures can have a more direct impact on how laws are actually enforced.

No one should think of extraterritorial enforcement as a magic elixir. Even the use of coercive domestic legal authority can fail to affect patterns of enforcement in other countries. Most notably, U.S. authorities have to know about a deficiency - otherwise it would make no sense to impose drastic measures essentially at random. But if U.S. authorities decide that banks in the Cayman Islands or Austria engage in secret transactions that pose a threat to national security, they can take action using domestic law. ${ }^{72}$ The question is not whether the U.S. government has the legal power to do this, but instead whether it has the capacity to detect offenses and respond dynamically to what it detects. This leads to the problematic question of the gap between state capacity and state power.

\section{A Proliferation of Laws Targeting Criminal Finance}

Upon reflection, the principled case for the global attack seems like a subtle one. Its merits depend on critical assumptions, on the precise nature of the laws at issue, and on the way those laws are applied. Moral intuitions provoke outrage for some, but even those intuitions become less stringent when it comes to imposing severe vicarious punishments on jewelry merchants who turn out to be helping alien smugglers wash their profits without direct knowledge that they were assisting a criminal network. Meanwhile, the utilitarian paradigm helps make the case for such an attack, though it is a case that depends on various assumptions and qualifications (for example, that some feasible version of the attack can impose a sufficiently high marginal cost on traffickers and terrorists). Despite all this, the reaction from the United States and a growing number of countries has been anything but subtle when it comes to expanding legal power. These nation-states have promulgated a hefty package of criminal laws, regulations and civil penalties that epitomize the ascendancy of indirect liability in the world of criminal finance.

For example, in the United States, prosecutors and investigators use criminal statutes for both domestic and extraterritorial enforcement connected to the global attack on criminal finance. The statutes criminalize uses of money derived from a long and growing list of specified unlawful activities. ${ }^{73}$ A number

71. 50 U.S.C. $\$ 1701$ (2003). Cases interpreting IEEPA powers in relation to terrorist financing are not uncommon. See, e.g., Holy Land Found. for Relief and Dev. v. Ashcroft, No. 02-5307, 2003 WL 21414301 (D.C. Cir., 2003) (using IEEPA in conjunction with terrorist financing); U.S. v. Reyes, 270 F.3d 1158 (7th Cir. 2001) (exporting military aircraft parts to Iran); U.S. v. Mechanic, 809 F.2d 1111 (5th Cir. 1987) (using IEEPA in conjunction with exporting microwave calibration devices).

72. See, e.g., Austria Yields Over Accounts, Fin. Times, Aug. 1, 1996.

73. See 18 U.S.C. $\$ \S 1956,1957$ (2001). 
of statutes also criminalize the financing of offenses. ${ }^{74}$ These laws are not only used for domestic prosecutions, but also for prosecutions targeting extraterritorial conduct. ${ }^{75}$ The point of extraterritorial enforcement is to reach people who affect a nation's interests even if they did not engage in actions that are within the territory of the nation-state. ${ }^{76}$ Couple this with the expanding scope of what is considered to fall within the "interest" of a nation-state, and the result is that limits on criminal prosecutions against criminal finance arise from practical constraints on the use of legal power rather than prudential limits arising because politicians are uncertain about their capacity to target the most deserving offenders. Some of those practical constraints in carrying out investigations may be diminishing because of the growing presence of U.S. law enforcement agents around the world. ${ }^{77}$

There is no doubt that the threat of criminal investigation and prosecution can deter and incapacitate some offenders around the world. ${ }^{78}$ But while U.S. prosecutors and investigators obtain convictions against hundreds of people involved in criminal finance every year, the larger question is whether the people investigated and prosecuted are the ones involved in the most dangerous kinds of criminal finance. This does not seem to be the case. Instead, the existing pattern of enforcement seems to be affected by the interaction of two important forces. First is the impact of low thresholds established by the elements of criminal offenses, which allow people to be convicted of money laundering or similar offenses even if they have not engaged in particularly complex or distinctive financial activity. ${ }^{79}$ Second is the effect of the limited scope of detection strategies that investigators working on criminal cases have at their disposal to detect criminal financial activity, which include informants and intelligence reports, as well as undercover activity, and currency-intensive enforcement at ports of entry. ${ }^{80}$ This raises the question of whether civil penalties and regulatory authority can help fill the gap in detection strategies.

74. See, e.g., 18 U.S.C. \& 1956(a) (2003) (establishing the offense of intending to promote the carrying on of a specified unlawful activity through the transnational transportation of money); 18 U.S.C. $\$ 2339$ (2000) (criminalizing material support of terrorism).

75. See, e.g., 18 U.S.C. $\$ \S 2339 \mathrm{~B}$ (d) (2001)(providing extraterritorial jurisdiction over the offense of providing material support or resources to designated foreign terrorist organizations); 18 U.S.C. § 1956 (f) (2001) (providing extraterritorial jurisdiction over money laundering if the conduct is by a United States citizen, or occurs in part in the United States and involves transactions with a value over $\$ 10,000$ ).

76. See Mark W. Janis, An Introduction to International Law 318-26 (4th ed. 2003) (naming the major accepted bases under international law for the assertion of jurisdiction by a domestic court: (1) territoriality-including both traditional subjective and the more open-ended objective or effects test; (2) nationality of the person in question; (3) the protective principle (or "national interest"); (4) passive personality (i.e., nationality of the victim); and (5) universality).

77. See, e.g., Paul R. Pillar, Terrorism and U.S. Foreign Policy 80 (2003) (noting that by 2000 , the FBI had agents stationed in 44 countries).

78. See, e.g., James Q. Wilson, Thinking About Crime 121 (Rev. ed. 1983) ("People are governed in their daily lives by rewards and penalties of every sort. . . . To assert that 'deterrence doesn't work' is tantamount to either denying the plainest facts of everyday life or claiming that would-be criminals are utterly different from the rest of us.").

79. See Cuéllar, Tenuous Relationship, supra note 14, at 404-10.

80. Id. at $410-20$. 
Policymakers act as though the answer is yes. Through regulatory rules and civil penalties, they impose duties on business firms and the public. Rules can require the collection of information, the restriction of some kinds of financial transactions, or the reporting of suspicious activities. United States antilaundering regulation, the model for such activity abroad, shows the breadth of this approach. Since about 1970, anti-money laundering regulations in the United States and later, in a number of other countries, have been developed with two purposes: (a) giving financial institutions a reason to cooperate; and (b) gathering information that can be used to detect and prosecute offenses. In the domestic context the regulatory approach generates (at least in theory) a lot of relevant information, especially on currency, and some legal pressure for banks and other financial institutions to report suspicious activity. ${ }^{81}$ Along with the regulatory approach, prosecutors have made increasing use of civil (as well as criminal) forfeiture provisions to seize assets allegedly connected to criminal activity. This civil and regulatory agenda intersects with the substantial emergency economic powers held by some executive authorities to impose sanctions, issue regulatory rules, and block assets. In the United States, the result is that an ambitious set of goals embodied in the anti-laundering system has been amplified by regulatory powers originally designed to bolster presidential authority in the midst of a military conflict.

The American experience also shows how emergency powers can be used in the hopes of advancing the global attack. Since early in American history, presidents have been invested with substantial economic powers to use during national security emergencies. ${ }^{82}$ President Jefferson asked for and received from the legislature the power to declare embargoes, and President Lincoln, to blockade ports. Executive branch officials in other countries are also endowed with considerable emergency powers. ${ }^{83}$ The passage of time showcases two trends concerning these powers in the United States ${ }^{84}$ First is the growth of a bureaucratic and administrative system that helps translate legal decisions into regulatory mechanisms targeting assets. The Treasury Department's Office of Foreign Asset Control is the lynchpin of that system. As the U.S. financial system has become a more attractive conduit for cross-border financial transactions, the regulatory system has further developed the capacity to reach ever more financial activity. The second trend is a move away from defining national security exclusively in geo-strategic military terms. Instead American policymakers emphasize that national security is threatened by terrorism, transnational

81. Id. at $352-64$.

82. See, e.g., Harold Hongju Koh \& John Choon Yoo, Dollar Diplomacy/Dollar Defense: The Fabric of Economics and National Security Law, 26 INT'L LAW. 715, 723-25 (1992).

83. See, e.g., Michael Freeman, Freedom or Security: The Consequences for Democra. cies Using Emergency Powers to Fight Terror (2003); Imtiaz Omar, Emergency Powers and the Courts in India and Pakistan (2002); Kurdish Human Rights Project, Due Process: State Courts and Emergency Powers in South-East Turkey (1997); Venelin I. Ganev, Emergency Powers and the New East European Constitutions, 45 Aм. J. Comp. L. 585 (1997).

84. As I discuss in the next subsection, the trajectory of the law in the United States has also been reflected in the aspirations contained in international agreements and treaties. 
criminal activity like drug trafficking, and even corruption. ${ }^{85}$ Put these two trends together and the direction of regulatory policy in this area becomes clear: a system, transnational in scope, with the power to regulate assets for broadlydefined national security goals. ${ }^{86}$

That power continues to grow. In the United States, regulators can impose "special measures" on countries that do not cooperate in the global attack, restricting their access to financial institutions based in the United States. ${ }^{87}$ This complements existing law by providing a mechanism for blocking the property of persons and organizations thought to pose national security threats to the United States. One recent executive order uses the President's authority under the International Emergency Economic Powers Act (IEEPA), ${ }^{88}$ and other laws to establish a process to block the assets of persons and organizations connected to terrorism. ${ }^{89}$ The executive order says little if anything about the process through which people or organizations should be evaluated for "connections" to terrorism. Even people or organizations that are merely "otherwise associated" with people or organizations believed to be controlled by those who are suspected of supporting terrorism can have their assets blocked. ${ }^{90}$ The regulatory

85. See, e.g., White House, United States International Crime Control Strategy (May 1998), available at http://www.usdoj.gov/criminal/press/iccs.htm. The document explicitly identifies an amorphous category of "financial crimes" (presumably including money laundering as well as fraud and the financing of crime) as a national security threat, stating that "[f]inancial crimes pose a national security threat because they threaten the integrity of the financial system while fueling numerous other types of criminal activity."

86. Similar trends exist in a few other countries with large economies. Indeed, in its influential "40-Recommendations," the OECD-supported Financial Action Task Force calls on all nations to ensure they have the legal power to "freeze, seize, and confiscate. . proceeds from money laundering or predicate offenses, instrumentalities used in or intended for use in the commission of these offenses, or property of corresponding value." Financial Action TAsk Force, FATF Forty RecOMMENDATIONS (2003), available at www.fatf-gafi.org/40Recs_en.htm.

87. See id. at $\S 311$.

88. 50 U.S.C. $\$ \S 1701-17$ (2003).

89. See Blocking Property and Prohibiting Transactions With Persons Who Commit, Threaten To Commit, or Support Terrorism, Exec. Order No. 13,224, 66 Fed. Reg. 49079 (Sept. 23, 2001) (Pres.) [hereinafter Executive Order 13,224]. The order provides in relevant part that property or interests of specific individuals and organizations listed in the order are blocked:

....(b) foreign persons determined by the Secretary of State, in consultation with the Secretary of the Treasury and the Attorney General, to have committed, or to pose a significant risk of committing acts of terrorism that threaten the security of U.S. nationals or the national security, foreign policy, or economy of the United States;

(c) persons determined by the Secretary of the Treasury, in consultation with the Secretary of State and the Attorney General, to be owned or controlled by, or to act for or on behalf of those persons listed in the Annex or those persons determined to be subject to subsection 1(b), 1(c), or 1(d)(i) of this order;

(d) .... Persons determined by the Secretary of the Treasury, in consultation with the Secretary of State and the Attorney General. . . to assist in, sponsor, or provide financial, material, or technological support for, or financial or other services to or in support of. . . . acts of terrorism. ...

The USA PATRIOT Act also expanded the scope of authority to engage in asset freezes and forfeitures. See, e.g., USA PATRIOT Act, $\S 323$ (allowing the government to use a restraining order to freeze assets in the United States).

90. See Executive Order 13,224, supra note 89, at Section (d)(ii) (subjecting persons to blocking when they are "otherwise associated with those persons listed in the Annex to this order or those 
side of the attack therefore serves two different objectives. One is the support of a generalized effort to raise costs for unknown offenders, for example, by requiring financial institutions to have anti-laundering programs and to report some suspicious financial activity as a supplement to other detection strategies. The other is to mete out some punishment against people whom the state has determined deserve it.

In the United States, laws targeting criminal finance are used aggressively to impose economic sanctions on individuals and organizations, or to target certain classes of common offenders like midlevel drug distributors and perpetrators of financial fraud. ${ }^{91}$ In some ways this attention pays homage to the power of the imagery of the criminal financier-to the perceived moral reprehensibility of one who seems both entirely guilty and also respectable. The criminal financier may seem like the representative of nearly all that is wrong with the world: he is at once a terrorist, perhaps a drug trafficker, one who can lure developing countries back towards corruption. There may be some support for all of these images, though the most important part of the dynamic here is something else: the rhetorical devotion to the global attack may work to strengthen the perceptions of the domestic and international audiences that made the global attack politically attractive in the first place. ${ }^{92}$ But if the global attack is going to get anywhere, its laws must allow nation-states to substantially alter the lucrative relationships greasing the wheels of the criminal economy.

II.

\section{The Mismatch Between State Power and State Capacity}

Most laws are described in principle as expressions of a public desire to solve a public problem. Whether it is a treaty or a domestic statute, the purpose

persons determined to be subject to subsection 1(b), 1(c), or 1(d)(i) of this order"). Even when executive branch officials discuss asset freezes, they describe the basis for an asset freeze as merely a "belief" (which is consistent with the broad discretion provided by the statute). See, e.g., Letter to the Honorable F. James Sensenbrenner, Jr., Chairman, Committee on the Judiciary, U.S. House of Representatives, from the Office of Legislative Affairs, U.S. Department of Justice, regarding the USA PATRIOT Act 30 (May 13, 2003). The letter contains responses from the Department of Justice to the House Judiciary Committee regarding the USA PATRIOT Act and the legal aspects of the war on terrorism. The letter notes that “. . the Seventh Circuit upheld Treasury's freeze on the assets of Global Relief Foundation, which is believed to have supported Osama bin Laden, al Qaida, and other known terrorist groups" [emphasis added]. The Justice Department also seemed to fudge the question of whether it had occasion to use new forfeiture powers provided by the USA PATRIOT Act, which the Department described as essential to the war on terrorism following September 11. See id. ("In most terrorism cases, it has not been necessary for the Justice Department to seek forfeiture of United States based terrorist assets under the USA PATRIOT Act's new authorities, because the assets had already been frozen by OFAC."). This underscores the value of asset freezes as a substitute for forfeitures, which (even before USA PATRIOT Act relaxed the standards) are essentially discretionary.

91. See Cuéllar, Tenuous Relationship, supra note 14, at 404-25 (discussing patterns of charging and conviction for money laundering offenses).

92. Whatever the attraction of rhetoric supporting the global attack, it is an altogether different question whether the global attack earns political support among interest groups, particularly financial services providers, who have to deal with its regulatory reach. In general such groups resist the global attack, at least its regulatory manifestation. See Cuéllar, Tenuous Relationship, supra note 14, at $448-49$. 
of a law is to create the capacity to address the threat of terrorism, the human cost of trafficking in persons, or some other dreaded activity. Few people would expect the capacity of the law to be anywhere near perfect. Yet beyond the sort of slippage in any human venture may lurk forces that systematically create and sustain gaps between power and capacity. Ignoring transnational threats may be risky, but so is ignoring the potential costs of just living indefinitely with the gap between power and capacity.

\section{A. Power and Capacity Distinguished}

The key to understanding the global attack on criminal finance is to distinguish between goals and actual enforcement practices, and particularly between the two major factors that drive those enforcement practices: power and capacity. I define state capacity as a state's ability to achieve its stated objectives. Capacity lets a nation-state materially reduce the most significant threats, stop the most dangerous terrorists, detect its most corrupt public officials, and punish the most important leaders of criminal networks. In contrast, power is the nation-state's authority to legitimately coerce individuals or organizations. Governments expand their legal power through expansively-worded criminal statutes that can easily lead to a conviction, and through regulatory provisions making it easy to freeze assets, forfeit property, and levy civil penalties.

Some countries experience direct problems with both power and capacity. These are the ones that run into problems running an electric power grid, keeping courts open, ensuring worker safety, and enforcing the law. It should not come as a surprise that these countries would also run into trouble attacking criminal finance. Thus, states such as Nigeria, Liberia, or Russia should not be expected to be effective in the global attack. ${ }^{93}$ These countries are saddled by technical problems, exacerbated by pressure from kleptocrats eager to frustrate capacity-building. Because of their limited power and capacity, developing states are likely to remain attractive jurisdictions for engaging in financial transactions connected to crime. The reason is that those states' mix of limits on power and capacity turns them into breeding grounds for corruption, which results in opportunities to engage in large, anonymous financial transactions. These opportunities themselves create further opportunities for corruption, since it becomes easier to buy off government officials and law enforcement officials through secret financial transactions. In contrast, developed nation-states have little, if any, trouble asserting their legal power over people or organizations that violate the law. Constraints on power are not completely missing in developed countries; however, the constraints tend to come from interest groups that might be even more inclined to frustrate regulatory rules and information-gathering requirements that can build capacity.

What the preceding suggests is that the extent of any effort to equilibrate capacity and power depends on a constellation of circumstances that would

93. See, e.g., Russian Money Laundering, Hearings Before the Committee on Banking and Financial Services, U.S. House of Representatives (106th Cong., 1st Sess.) (Sept. 21-22, 1999). 
rarely arise in either developed countries or their developing counterparts. Interest groups and the public would have to care about the mismatch. They would also need information about whether there was a problem, or at least some basis to believe there was a problem in matching power and capacity. Otherwise the gap could continue unencumbered, producing a sort of prophylactic criminal and regulatory enforcement that targets people engaged in activity believed to be intimately tied to a deeper harm. This is not an unusual pattern in criminal and regulatory enforcement. However, this pattern is exacerbated when the indirectly harmful activity is defined as an integral part of that enforcement and when politicians and government officials believe they will benefit from showing progress on a popular enforcement priority (such as the "war on terrorism").

The mismatch between power and capacity can create some problematic scenarios. Statutes and regulations designed to serve a prophylactic purposelike the prohibition against operating an unlicensed money transmitting business - can be coupled with severe criminal penalties that help a government send a message about their response to a threat. ${ }^{94}$ Once these criminal and regulatory laws are justified as essential to an important purpose (such as fighting drug traffickers or stopping terrorism), they can be used against targets that may be only tangentially connected to the dreaded activity. Thus nation-states may build up power but neglect capacity because it is less visible, or because capacity-building would require regulations that impose costs on organized interest groups. All of which implies that the disequilibrium between power and capacity should not be ignored.

\section{B. The Forces Creating a Power-Capacity Mismatch}

I have demonstrated that power and capacity are different, but I have not yet explained why the laws attacking criminal finance might reflect such a dramatic disconnection between power and capacity. As I explain below, there are strong forces that would tend to keep power and capacity separated in the fight against transnational crime.

\section{The Impact of Detection Difficulties}

Detection difficulties can skew the allocation of penalties to offenders that are easier to find. If law enforcement officials have an interest in meting out punishment, but the marginal cost of detecting the more serious offenders outstrips the marginal additional benefit to the official of catching the most serious offender, then the result is that offenses that are routinely punished are likely those that are fairly easy to detect. The easily detected offenses are not necessarily likely to be the ones that merit the most attention in terms of either national security or some deep normative sense. There is no compelling reason to think that the difficulty of detecting an offense will vary inversely with the "serious-

94. The legislative history of the major laws targeting money laundering and criminal finance are filled with clear statements about why the enforcement efforts are being pursued, but these scenarios bear little connection to the routine uses of the criminal penalties. See Cuéllar, Tenuous Relationship, supra note 14 , at $395-97$. 
ness" of the offense, measured in any number of ways. One might imagine the "seriousness" could simply refer to how severely an offense is sentenced, although the comparison may become less meaningful given the law's role in grouping different practices and defining them as "similar" enough to constitute the same offense (often with a similar range of sentences). An alternative approach to assessing how "serious" an offense is would be to ask whether the offense detected bears some resemblance to the paradigmatic ones that spurred legislators or other politicians to champion a particular enforcement program. Here the fight against one kind of criminal finance-money laundering - reveals a big disconnect between the "paradigm cases" and routine prosecutions. In the United States and many other countries, the fight against money laundering was most often justified in terms of three objectives: new methods for detecting crime, targeting third-party launderers who could use special skills (or professional cover as accountants, bankers, and lawyers) to launder money, and targeting leaders of criminal networks who could amass tremendous concentrations of wealth from illicit activities. Instead, conviction patterns show a focus on predicate offenders with no particular skill or ability at managing international financial flows, and who were often discovered using traditional law enforcement methods.

What about the rest of the attack on criminal finance? My primary objective is to establish that there is no reason to assume that the most serious or despised offenders would be the ones that are easiest to detect. On the contrary: most committed organizers of terrorist plots, corrupt central bankers, and leaders of narcotics smuggling networks are likely to have in common a strong desire to avoid being caught, combined with the skills and resources to make themselves harder to detect. ${ }^{95}$ The greater the mismatch between offenders who are easy to detect and those who plausibly could be described as the most "serious" offenders, the more it is necessary to think about the unintended consequences of a particular enforcement scheme.

\section{Uncertain Impact of Legal Changes in Reluctant States}

Strategies using FATF and other transnational measures may force some states to make cosmetic changes in their laws. But new criminal statutes rarely achieve lasting differences in enforcement patterns. More profound changes seem to depend on more drastic transformations in political, economic and cul-

95. For a note on what I mean by "serious" offender, see supra note 2. Serious offenders might be especially difficult to detect for a few reasons. Presumably punishment is more severe for many offenders that might defensibly be termed "serious" (for example, the major financial backer of a terrorist scheme when contrasted to a person convicted of operating as an unlicensed money transmitter). Even mildly rational offenders would be more interested in avoiding punishment as the severity of the punishment drastically increases (though the extent of disutility that offenders face per unit of punishment likely diminishes with the extent of punishment). Leaders of criminal networks and corrupt offenders amassing substantial financial resources, moreover, would likely have a lot to lose if they are wealthy, and should be willing to spend their resources on remaining beyond the grasp of law enforcement. They could do so by investing in the technical capacity to hide money in offshore trusts and anonymous corporations, by purchasing services from government officials (including law enforcement officials), and by procuring the assistance of third-party launderers. 
tural incentives for government officials and businesses. This is at least what the American experience implementing the fight against the related offense of money laundering seems to show.

It is worth saying a little about some of the forces that might be affecting that spread. As I suggested above, the United States and other developed countries have adopted the attack on criminal finance for reasons involving political symbolism as much as anything else. Executive branch officials and legislators respond to political pressures, so they are likely to promote a version of the attack on criminal finance acceptable to powerful interests, such as financial institutions. While these interests will not get everything they want, it is impossible for politicians and executive branch officials to completely ignore outside interest groups that are sufficiently organized to challenge executive policy through a combination of political pressure, economic pressure, and litigation. Thus politicians in developed countries should be expected to shape laws in response to the competitive environment in which they operate. Their personal views about the importance of attacking criminal finance would then develop within a particular set of constraints.

The situation in developing countries is not entirely different. ${ }^{96}$ Some smaller jurisdictions obviously have a vested interest in bank secrecy because it allows them to compete for funds in the world market. Along with other developing countries, these jurisdictions might find it attractive to join the global attack on criminal finance only in principle. No doubt in some cases, policymakers in these countries could occasionally harbor a genuine interest in pursing the global attack, ${ }^{97}$ but they might also be enticed to join the global attack in response to more coercive forces. The United States and its allies can exert pressure along the lines I describe below, yet ironically the cost of implementing legal measures against criminal finance may not be prohibitive, even for countries with a stake in bank secrecy. As I have explained elsewhere, the key is that legal changes do not necessarily determine the reality of how laws are enforced-that depends on factors that states still control, like budgets, prosecutorial discretion, and detection strategies used by investigators. ${ }^{98}$ Add to this what may be a perception that in order to be considered a developed economy, states should develop the bureaucratic and legal structures that attest to their commitment to the fight. ${ }^{99}$ Yet the substantive impact of these changes remains questionable.

96. Cf. James Raymond VReeland, The IMF and Economic Development 53-54 (2003) (discussing the impact of the interest group environment on politicians and their economic policy choices in developing countries receiving IMF assistance).

97. For example, think of a situation where a newly-elected president of a developing country faces a government with persistent corruption problems. As a response to this problem, the president manages to impose new reporting requirements on major banks and financial disclosure requirements for senior government officials and their families. The president and her administration might therefore decide that it makes sense to pursue the global attack.

98. See Cuéllar, Tenuous Relationship, supra note 14, at 438.

99. Cf. Goodman \& Jinks, supra note 55 . 


\section{Political Incentives to Use Power Without Capacity in Developed Countries}

Executive branch officials in more developed countries face their own constraints. They may find themselves under pressure to show results in the proverbial wars against those offenses alleged to benefit from criminal finance, such as terrorism and drug trafficking. The more power the laws allow the executive to exercise on a discretionary basis, the more tempting it may be for the executive to use such power regardless of whether there is the capacity to target the sanctions at the most deserving targets. Furthermore, interested parties may see costs associated with building capacity, which could spur them to act against capacity-building.

Let me expand on this argument. The executive branch of government can use many of its legal powers without interference from courts or legislators. ${ }^{100}$ Suppose that something like a domestic terrorist attack happens, making voters feel threatened-what economists call an exogenous shock. For both affective and rational choice reasons, it makes sense to think voters will want to see their government use its legal authorities to punish those responsible for the attack and to respond to the perceived threat of future attacks. The affective motivation is driven by the desire of many voters to think about the world as being predictable and just in some sense-such that a harmful action against them (or their polity) is met with some corresponding government action. ${ }^{101}$ Many voters would cringe if the government's major response to an attack consisted of a slow and uncertain search for evidence in a criminal case. The global attack on criminal finance, driven increasingly by executive powers rather than criminal statutes, may serve as a comforting sign that harmful actions are quickly met with guarding reactions. Making the attack focus on finance also captures moral intuitions about who should be blamed for harms. Financing undesirable activity or willfully enjoying the profits seems at least as bad as pulling the trigger, lighting the fuse, or physically imprisoning trafficked women. ${ }^{102}$ The implication is, moreover, that the global attack on criminal finance targets people who would otherwise evade punishment under traditional criminal laws. Often this is technically true, because executive powers do not require legal and procedural formalisms that the criminal process does. It is precisely for this reason, though, that there are fewer guarantees about whether people or organizations targeted in the global attack deserve to be subjected to asset freezes or similar measures.

100. Cf. Terry M. Moe \& William G. Howell, The Presidential Power of Unilateral Action, 15 J.L. ECON. \& ORG. 132 (1999).

101. See generally M. J. Lerner, The Belfef in a Just World: A Fundamental Delusion (1980); M. J. Lerner \& D. T. Miller, Just World Research and the Attribution Process: Looking Back and Ahead, 85 PsYchol. Bull. 1030 (1978); M. J. Lemer \& C. H. Simmons, Observer's Reaction to the Innocent Victim: Compassion or Rejection?, 4 J. Personaltry \& Soc. Psychol. 203 (1966).

102. Cf. Robert Chesney, Civil Liberties and the Terrorism Prevention Paradigm: The Guilt by Association Critique, $110 \mathrm{MICH}$. L. REv. (forthcoming 2003) (defending statutes criminalizing material support of groups designated by the government as supporting terrorism, where material support includes providing money to the relevant groups). 
The rational choice dynamic affecting the use of government power without capacity in the global attack is slightly different but leads in the same direction. Imagine that voters want to reward politicians not just for appearing to deal with a threat, but for actually reducing the threat. Unfortunately, changes in that threat are difficult to measure; indeed, changes in the threat attributable to specific legal or policy changes are even more difficult to assess. Given the existence of laws like IEEPA, politicians and the government officials that they oversee have access to executive powers that can be used regardless of whether their use has much of an impact on the threat. The use of the executive powers to pursue the global attack then becomes like a form of "cheap talk" for politicians-if politicians did have the means of using their powers to reduce the threat, then surely voters would be able to observe it because politicians would be using their legal authority. ${ }^{103}$ This means that politicians and the government officials they oversee would have an incentive to use their substantial, existing legal authorities in the global attack. The incentive is there even if government officials question to what extent asset freezes under IEEPA or similar measures actually reduce national security risks. ${ }^{104}$

The problem of power-capacity gaps becomes worse because sometimes building capacity may require regulatory enforcement and programs that are costly to certain interest groups. Thus, banks and financial institutions have tended to fight expansions in regulations that yield information about when violations are occurring. ${ }^{105}$ Thus developed countries may trumpet their twentyfirst century banking supervision, but they may face some of the same constraints that developing countries do: their regulatory policy and implementation

103. See, e.g., David Austen-Smith, Information Transmission in Debate, 34 Am. J. Pol. SCI. 124,125 (1990) (describing cheap talk as costless or near-costless communication).

104. What makes it difficult to draw conclusions here is that national security threats are hard to measure. Which means that a government official may not be genuinely dishonest when he says that something like an IEEPA designation contributes to national security. After all, the contribution to security might be understood in at least two different ways: either "it will make a measurable difference in security," or "I can imagine a scenario, of uncertain and perhaps even small probability, where IEEPA designations are part of a broad pattern that helps reduce the threat." For an example of the latter approach, see Terrorist Financing: Report of an Independent Task Force SponSORED BY THE COUNCIL ON FOREIGN RELATIONS 24-6 (2002), available at http://www.cfr.org/pdf/ Terrorist_Financing_TF.pdf. The important point is this: given the availability of this latter justification (that is, the possibility that a scenario can be envisioned), then politicians can respond to the incentives favoring some kind of national security activity and still be "honest" in some sense of the term when they say that they believe they are making a contribution to national security. The question then becomes how to characterize facts that lend plausibility to the government's interpretation. See, e.g., Eric Lichtblau, Court Papers Show Charges That Group Aided Terrorists, N.Y. Times, October 18, 2003 (describing a five-year federal law enforcement investigation of a network of charitable and educational institutions suspected of laundering hundreds of thousands of dollars to help finance terrorist attacks that has yielded few prosecutions).

105. See Cuéllar, Tenuous Relationship, supra note 14, at 449 n.469 (describing banks' efforts to stop currency reporting requirements designed to enhance law enforcement capacity to identify criminal financial activity). See generally Terry M. Moe, The Politics of Structural Choice: Toward a Theory of Public Bureaucracy, in Organizational Theory: From Chester Barnard to the Present AND Beyond 328-29 (Oliver E. Williamson ed., 1995) ("A bureaucracy that is structurally unsuited for effective action is precisely the kind of bureaucracy that interest groups and politicians routinely and deliberately create. .."). 
depends on what politicians have the will and opportunity to accomplish, which in turn depends a good deal on what interest groups will allow.

What if there was some way for the executive to "signal" that he is really developing capacity? ${ }^{106}$ Imagine first a world in which an important segment of the mass public decides whether to support the executive using a simple rule of thumb: if the executive appears to be doing something constructive to reduce a threat, then he should be evaluated more positively than if he does not do so. Imagine further that the basis for using this rule of thumb is a simple effective response to a dreaded uncertainty. If people are facing an unknown threat, they obtain greater satisfaction knowing that they are not merely steeped in futility, but are instead part of a state whose government is responding to the threat. In a world like the one just described, it is not surprising that politicians would have an incentive to use their legal powers even in the absence of capacity to focus those powers on the most deserving targets. Members of the naïve public would take the mere decision to freeze assets or impose special measures on a country as a basis to reward the executive. In this scenario, the decision to use legal powers is itself taken as the signal, because (the naïve voter concludes) it would be silly for the executive not to use the expansive legal powers if the capacity really was there to target the important offenders. This dynamic might lead to asset freezes against some charity, for example, even if there is little basis for such an action. This state of affairs, in turn, may send the charity a message that its conduct does not matter much since it might face asset freezes regardless of what it does. ${ }^{107}$

106. In recent years, political scientists have studied the implications of signaling in strategic situations such as the escalation of international disputes. See generally JEFFrEy S. BANKS, SignALIng Games in Political Science (1991). When the outcome of a game depends on some characteristic about one of the players that cannot be directly observed (for instance, how resolute a certain nation-state is to prevail in a conflict), that player can affect the outcome by sending a costly "signal" designed to credibly demonstrate that he is a certain kind of player. Depending on the characteristics of a game, a politician might be able to "signal" a sophisticated voter to indicate that he is willing to invest in capacity (which is not observable until the game ends and the payoffs are awarded). The players can send costly signals that help show voters whether they are the type who would (or have already) invest(ed) in capacity. The problem is, the costly signal is not always enough to sort the players in accordance with their "true" type or actions. Some equilibria are "separating" or "semi-separating" in the sense that the politicians do sort themselves into different categories that correspond to what the other player wants to find out. But "pooling" equilibria are also possible, where all the players adopt the same strategy of sending the costly signal. For a discussion of the impact of signaling among nation-states engaged in strategic interaction, see James Morrow, Modeling the Forms of International Cooperation: Distribution Versus Information, 48 INTL. ORG. 387 (1994).

107. The use of power would not work this way unless the executive could find some targets to punish that could be plausibly linked to the underlying threats that voters fear. Such links are rarely self-explanatory in transnational law enforcement, so the executive has to provide a compelling enough narrative to explain why catching an unlicensed money transmitter in Brooklyn or freezing the assets of a charity reduces the threat of terrorism. My analysis here assumes this is not that hard for the executive. The executive tends to have a lot of resources to articulate the desired narrative around visible actions that can be easily covered by the media, and the media coverage in turn shapes voters' perceptions of what issues matter. $C f$. SHanto Iyengar \& Donald R. Kinder, News That MatTers 72 (1988) (using experimental evidence to establish that "by providing glimpses of some aspects of national life while neglecting others, television news helps define the standards that viewers apply to presidential performance"). Moreover, many voters use mental 
The question is then what happens when we make different assumptions about the nature of the signal and voter sophistication. Suppose that some fraction of the electorate consists of sophisticated voters who are making rational decisions and that they care about rewarding an executive who develops capacity and uses power only when there is some degree of capacity. Suppose further there is some costly bundle of policies that, if adopted, allow the executive to send a credible signal to sophisticated voters about his interest in developing capacity. The policies could include appointing a technocrat to run a law enforcement bureaucracy, raising the threshold of proof necessary to use some legal powers, or making classified information public. As the appendix demonstrates, this state of affairs may encourage the executive to send signals that he is building capacity. But this happens only if the proportion of sophisticated voters that the executive needs to achieve some political objective (for example, reelection) is sufficient to offset the executive's cost of sending the signal. ${ }^{108}$

The scenarios described above all reflect an assumption that the major goal of the executive is pleasing voters. Yet sometimes executive branch officials may have other objectives besides pleasing voters. These objectives may be acceptable or problematic depending on where you stand ideologically, but the global attack suppresses much of the debate about them. For example, some executive branch officials might be interested in imposing punishments on people or organizations to advance prosecutorial agendas. Organizations targeted with asset freezes may then have an incentive to cooperate with government to help it make cases against other organizations and individuals in order to avoid asset freezes. Money transmitters targeted with severe penalties under new statutes prohibiting illegal money transmission may be eager to provide information on people and organizations considered to be suspicious, or even just to plead guilty to a lesser offense. Executive branch officials may be interested in using the global attack to advance prosecutions and punitive measures against suspected offenders, regardless of whether those offenders are the despised villains that justified the legal powers associated with the global attack. Government officials may also have a particular vision of national security that can be ad-

short-cuts to evaluate security policy. The short-cuts they use may only rarely lead them to copiously scrutinize the executive's arguments about how a particular action enhances security. See, e.g., Milton Lodge, Kathleen M. McGraw \& Matrick Stroh, An Impression-Driven Model of Candidate Evaluation, 83 AM. Pol. SCl. Rev. 399, 416 (1989) (using experimental evidence to establish that pleasing information about candidates and policy issues can affect subjects' support for candidates, even if the details of the information are not remembered subsequently). It would be helpful to have more empirical research on just how much leeway the government has in creating its narrative. Two factors are likely to shape the executive's flexibility to link small fish to big threats. One is the proportion of sophisticated voters that matter electorally, which the Appendix, infra, discusses. Another factor is the effect of racial, national origin, or similar characteristics. For example, if the public unconsciously links being Black or Arab to being threatening, it will be easier for the executive to construct its narrative when the target is Black or Arab. Cf. Rupert Brown, Prejudice, Its Social Psychology 8 (1995) (noting that some people develop and sustain negative affect toward people with particular racial or other ascriptive characteristics); Henry E. Brady \& Paul M. Sniderman, Attitude Attribution: A Group Basis for Political Reasoning, 79 AM. Pol. SCI. Rev. 1061, 1068 (1985) (suggesting that people's preexisting likes and dislikes of political groups drives some of their political attitudes when they use a "likeability heuristic" to interpret policies).

108. See Appendix, infra. 
vanced by imposing sanctions on regimes, organizations, and individuals thought to pose a threat. Just as asset freezes might help government officials convince voters that they know whom they should blame for attacks or threats, the imposition of sanctions can help convince voters that the sanctioned regime is a threat. ${ }^{109}$

\section{Substitution}

Some transactions are intensely difficult to regulate because people can use substitute systems to achieve their objectives. Even when they make some headway, it is hard to imagine that authorities ever constrain offenders' ability to engage in financial transactions that further their offenses. As explained above, it is difficult to know exactly how costly it is for potential offenders to substitute harder-to-detect transactions for more easily detected ones. Though some kinds of transactions that are especially desirable for offenders might be made more costly (either through administrative burdens or reporting requirements that increase the perceived risk of detection), the more relevant point is that extremely motivated offenders (say, those with an ideological motive to engage in terrorism) may be exceedingly difficult to stop.

The possibility of substitution effects is perhaps not surprising, since laws can trigger such behavior in many if not most situations where people trade-off the possibility of reductions in desired activity against possibilities of continuing those activities but evading legal penalties. To begin with, the detection difficulties described above make it harder to identify offending transactions within the financial system. But even if this were not a problem, non-state actors would still have ways of moving money around. Jurisdictions complying with the FATF Forty Recommendations on money laundering enforcement and Eight Special Recommendations on terrorist financing retain substantial discretion to engage in lax enforcement. If all states strictly abided by these recommendations, offenders would still have the option of trying new approaches ${ }^{110}$ or attempting to secede from the most heavily regulated components of the global financial system. These loopholes demonstrate how capacity also depends on the state's ability to enforce laws in the less-regulated nooks and crannies of the global financial system. One might question whether state capacity to regulate offshore and Internet financial transactions will expand indefinitely. For the criminal, substituting less regulated financial transactions probably entails some costs, including less convenience and perhaps lower return on investment. However, in many cases, those costs would still be less than the benefit of find-

109. The basic logic is the same: if the regime were a threat, politicians would impose the sanction. Failure to impose the sanction would make it harder for politicians to argue the regime is a threat.

110. See, e.g., Maria E. de Boyrie, Simon J. Pak, \& John S. Zdanowicz, The Impact of Switzerland's Money Laundering law on CaptTal Flows Through Abnormal Pricing in INTERNATIONAL Trade (Center for International Business and Education Research, Fla. Int'l Univ. Working Paper 2002) (presenting tentative evidence of a shift toward the use of false international trade invoicing involving trade between the United States and Switzerland after the latter country adopted more stringent anti-money laundering controls). 
ing alternatives to the more highly regulated financial transactions. Shell banks are one option. Moreover, not every transaction must involve the financial system at all. Barter, as well as financial information exchanges, give people an alternative for moving money. ${ }^{111}$

The preceding logic implies that depending on the offense in question, a change in the marginal price of achieving the transaction may or may not discourage someone from going through with the transaction. Thus, the global attack on criminal finance may be expected to have a different effect on drug traffickers than on terrorists. For drug traffickers, the disposition of marginal dollars can make the difference between a cost-effective operation and a moneylosing proposition. For terrorists, added expense may be problematic but not a deal breaker-at least as long as they can avoid detection before carrying out their objective.

III.

\section{Potential Consequences of the Mismatch}

Some would argue that the problems of capacity and power I have described are really not all that troubling. After all, as the argument goes, domestic and international laws targeting criminal finance are serving an expressive function, and every enforcement system harbors its own particular assemblage of faults. Such arguments for ignoring the gap between power and capacity are unconvincing without some elaboration. To judge law's impact one must understand how it is being enforced, and what consequences that enforcement might have. By the same token, altering the law's impact may call for changes not only in the content of a treaty or an extraterritorial statute, but in the incentives of the bureaucracies responsible for enforcing the law. The law's consequences are borne from its impact on the world, not just its aspirations. This section reviews the possible consequences of a persistent disequilibrium between power and capacity in transnational criminal enforcement, and the prospects for closing the gap.

\section{A. Implications}

While the mere existence of a gap between state power and capacity does not automatically undermine the principled argument for targeting criminal finance, under certain conditions the gap can have perverse effects once we consider the political context. Some might argue that this dynamic simply reflects the application of a principle akin to strict liability; that is, any allegation that a charity is participating in terrorist financing results in an asset freeze. But note that this argument implies that the worst consequence is futility. We might easily imagine another scenario where the worst that can happen is perversity. Suppose, for example, that some charities whose assets are frozen had made an effort to ensure their resources did not fund terrorists. If their assets are frozen

111. Cf. David Woodruff, Money Unmade: Barter and the Fate of Russian Capitalism (1999). 
and other charities making a similar effort believe they will face the same prospect, then those other charities' resolve to police the destination of their funds may weaken.

This dire scenario is not the only possibility. One could make assumptions that would make these perverse effects seem extremely unlikely. One might suppose, for example, that charities would never be tempted to contribute their resources to foreign organizations that were involved both in violent and charitable activity. But those different assumptions would need at least some justification, and that stands in contrast to the justifications offered by government officials in the U.S. defending the global attack on terrorist financing. For example, one government official recently defended the existing approach as follows:

We must remember that the problem underlying [our] concern is the abuse of charities by terrorist organizations. It is this abuse, not the consequential freezing actions taken by our government, which undermines donor confidence. In the absence of our designations, money intended for humanitarian assistance would not be frozen; rather, it would finance further destruction. ${ }^{112}$

The preceding statements assume that the designations are essentially correct, in the strongest sense of the term. The implication is that the asset freezes restrict the disposition of funds that would have otherwise financed destructive activity. This assumption is questionable given the incentives of the executive branch. Even if the assumption were plausible, the statement may not be convincing. There is an implicit presumption that if funds for humanitarian assistance and destructive activities are being commingled, the marginal additional dollar contributed would go to destruction. That is not obvious. Organizations commingling funds might have incentives to spend the marginal dollar on nondestructive activities. One might still come up with a theory of collective sanctions that would make it worthwhile to target an entire charity when any portion of its money appears to be going to destructive causes. At present, that kind of justification seems to be missing, or at least radically underdeveloped.

A defender of disequilibrated enforcement, like the official quoted above, might say that the global attack is just a reasonable step in the direction of strict liability. In such a world, letting even a crisp $\$ 5$ bill be diverted to destructive activities should be subject to severe sanctions, which would force it to internalize the cost of stopping the misuse. I have already noted the problems that exist when it comes to gathering information confirming that, indeed, the $\$ 5$ bill has been diverted. Beyond this, there is the question of whether strict liability makes sense in the many different battlefields where nation-states pursue the global attack on criminal finance. After all, there is nothing inherently wrong with strict liability. The problem is the potentially weak connection between what is supposed to trigger liability and what actually does trigger punishment. We cannot observe the extent of the disconnection directly, and we know from

112. U.S. Department of the Treasury, Office of Public Affairs, Written Testimony of David D. Aufhauser, General Counsel, U.S. Department of the Treasury, Before the Senate Judiciary Committee, Subcommittee on Terrorism, Technology, and Homeland Security (June 26, 2003). 
the analysis above that the executive may have incentives to use power even in the absence of capacity to target the most egregious offenders. Moreover, even if there were an explicit move toward strict liability for anyone engaged in a particular kind of transaction-a bank discovered to have been laundering money, or a charity alleged to have facilitated terrorist financing-there would still be at least three important questions to address. First is the question of the marginal benefit of a strict liability regime on the reduction of undesired conduct. Second is the question of the marginal cost of a strict liability regime, especially in terms of reductions in desired activity, such as the provision of remittance services. Third is the question of the fairness and efficiency issues raised by how discretion is applied in punishing the range of possible offenders. The contemporary global attack on criminal finance does not seem to represent a strict liability system justified on the preceding grounds. ${ }^{113}$

Regardless of the extent of justification, law enforcement officials can pursue the global attack through criminal prosecutions of offenses with elements that are fairly easy to prove (illegal money transmission), yet are still closely identified with larger, more popular enforcement objectives (fighting terrorism). The same is true for actions freezing assets. To the extent that the use of the powers themselves will serve as a signal to voters about state capacity, and to the extent voters care about this, the politicians and the law enforcement officials they oversee will have a big incentive to use the powers. The incentive will persist even if it is possible in principle to undertake a painstaking, potentially useful investigation into international money laundering or terrorist financing of uncertain results. The major counterweight to this pressure will come from officials and politicians who consider accuracy, fairness, or genuine gains in national security to be personal goals, or from bureaucrats who might bear a substantial cost as a result of opposition from targeted groups. But since voters reward what they can see, political pressures will tend to push law enforcers in the opposite direction. ${ }^{114}$

In contrast, building a painstaking case against an offender takes time and effort. It is a sort of wager: investigators, prosecutors, and executive branch officials are not guaranteed that an exhaustive investigation will uncover Osama Bin Laden's personal investment banker or the Cali cartel's top Bahamian banker. All of these people may still care about anonymity, but they may have strategies of varying costs to purchase financial anonymity despite the uses of some of the legal measures that lay the foundation for the global attack. ${ }^{115}$

113. Note that when it comes to civil remedies against alleged financial contributions to terrorism, the United States legal system rejects the notion of strict liability. See Boim v. Quranic Literacy Institute and Holy Land Foundation, 291 F.3d 1000 (7th Cir. 2002) (giving money to a group which then sponsors a terrorist act, without knowledge of 'donees' intended criminal use of the funds, did not constitute an act of international terrorism).

114. Cf. Daryl J. Levinson, Making Government Pay, 67 U. CHI. L. Rev. 345 (2000) (government tends to respond to votes, not dollars or anything else).

115. Moreover, although all of the preceding offenders may care about anonymity, the slope of the curve connecting anonymity to the demand for illegal acts may be different depending on whether the offender is, for example, a low level terrorist or the leader of a profitable drug smug. gling business. 
Not everyone will think that there is a problem if state power to attack alleged instances of criminal finance drastically exceeds the state's capacity to attack and constrain the most troubling instances of criminal finance. There are plenty of examples of legal authority that convey power but do not bestow on government the capacity to completely address a problem. Customs enforcement does not completely stop the flow of drugs. Laws against the sale of tobacco to minors do not prevent every enterprising fourteen year-old from getting his hands on some Lucky Strikes. Nonetheless, there is reason to be concerned about the mismatch between capacity and power in the global attack on criminal finance. Indeed, the disconnection between the most troubling threats and the actual targets of coercive power may eventually weaken the legitimacy of the global attack on criminal finance. Of course the meaning of legitimacy is contested. Its ebb and flow is admittedly hard to assess either conceptually or empirically. Still, some domestic or international constituencies may care about the connection between alleged threats justifying particular enforcement policies and the people actually targeted with those policies. Disequilibrated enforcement that works just fine in the short run may lead these constituencies to reduce their aggregate degree of trust in the state. ${ }^{116}$

Even on purely utilitarian terms, disequilibrated enforcement could be problematic because of its impact on opposition to the global attack, and the possible distrust from organizations, individuals, and groups targeted in the global attack. ${ }^{117}$ Regulatory asset freezes and low-threshold criminal prosecutions may even help engender a perverse dynamic, where people and organizations decide it is not worth their while to forego illegal conduct because they may suffer punishment anyway or because seeing instances of punishment that they consider unjustified produces a radicalizing effect. ${ }^{18}$ Defenders of disequlibrated enforcement would be quick to point out that draconian enforcement simply errs on the side of punishing those who have given the government rea-

116. Suppose, for example, a rational, sophisticated voter cares about making sure that legal powers are actually used to reduce the threats that justifies the existence of such powers. The voter observes the executive over several time periods. Assume further that the voter could observe both power and some signal that may or may not be related to capacity after each time period (for instance, the appointment of a trusted law enforcement official). After each time period, the voter could use Bayesian updating to react to the executive's repeated assertions of power without making an effort to develop the capacity to target the most egregious threats. $C f$. DREw FudenBERG AND JeAn Tirole, Game Theory 211 (1993). If a sophisticated voter were judging the politician over more than one period, the voter could update her beliefs about the probability that the assertion of power was also coupled with an effort to build capacity. After a few rounds of play, the sophisticated voters might decide to withdraw their political support. The equilibrium would depend on the payoffs for the voter and the executive (including the cost of the capacity-related signal), and on the players' assessment of various probabilities. If the politician refuses to build capacity after a few time periods, then the voter could suddenly withdraw her support after deciding that given the preceding behavior, the politician cannot be trusted.

117. See Cuéllar, Choosing Anti-terror, supra note 5, at 23 n.44 (2003) ("'OO]ne cannot state with certainty that racial profiling's benefits would dwarf the consequences of 'clamming up.' The only certain conclusion is that the 'clamming up' effect should not be ignored.").

118. See, e.g., Ru J. P. de Figueiredo, JR. \& Barry R. Weingast, Vicious CyCles: Endogenous Poltitical Extremism and Political Violence (University of California, Berkeley Institute for Governmental Studies, Working Paper 2000) available at http://www.igs.berkeley.edu/publications/workingpapers/WP2001-9.pdf. 
son to doubt that they are refraining from illicit activity. The problem is that it is hard to tell in advance what exactly will trigger a government reprisal. It is hardly the case that every affected charity is justified in complaining that its assets have been unfairly frozen. Still, it is also true that disequilibrated enforcement may have costs, skewing the incentives of charities that fear being targeted and potentially polarizing constituencies that are valuable in waging a war on criminal finance or terrorism.

Even if there were no risks of perverse radicalization, disequilibrated enforcement may provide a false sense of security when its most deserving targets elude capture. ${ }^{119}$ A few things might make this possible. One is the executive's ability to show voters what looks like progress by using legal powers without building capacity. Another is the low level of power or capacity in developing countries. Either way, there is some risk involved in having the machinery of the law hum along, generating asset freezes and arrests for illegal money transmitting, but little if any change in the marginal threat. Depending on one's assumptions about the sophistication of the public, the bustle created by the exercise of legal power might create a cascading impression among the public that there is no capacity problem at all. ${ }^{120}$

Finally, though states are building their power to wage the global attack, the low capacity means that scarce resources for the attack-including money, bureaucratic priority, diplomatic pressure, and regulatory enforcement-may be misallocated. At worst, the gap can even create a sort of spiral where demands for power grow with little attention on their marginal impact on capacity. This may not be true for every law enforcement agency in every situation. The point is that, in the panoply of political circumstances shaping law enforcement agency budgets and legal powers, the lack of capacity may play a role in the still further expansion of legal power. Intelligence and law enforcement failures are often the preludes to still further expansions of legal powers and financial resources for security bureaucracies. Unless distinctive circumstances create pressures on law enforcement officials and politicians to repeatedly and publicly scrutinize the connection between requested legal powers and the impact on capacity, law enforcers will have little to lose when requesting new powers. Thus the gap between power and capacity can grow ever larger for an extended period, even if a growing group of citizens may eventually question the legitimacy of law enforcement as a result. ${ }^{121}$

119. By "deserving," I mean "serious." See supra note 2 (discussing what offenses are "serious").

120. Cf. Timur Kuran \& Cass R. Sunstein, Availability Cascades and Risk Regulation, 51 Stan. L. REv. 683 (1999).

121. For a discussion of law enforcement officials' incentives to expand the scope of criminal laws in the domestic context, see generally William J. Stuntz, The Pathological Politics of Criminal Law, 100 MiCH. L. Rev. 505 (2001). Domestic criminal law may also involve a separation between criminal law powers and capacity to achieve criminal justice results. I leave for another day the questions of whether this dynamic is materially different, but some distinctions appear on the surface: domestic criminal prosecutors and police forces (especially local ones) operate subject to budget and political constraints driven by voters who can readily observe developments in regional criminal justice. Transnational threats can create intense fear and are more difficult to readily ob- 


\section{B. Prospects for Controlling the Mismatch}

Suppose that, despite the forces I have described as contributing to the mismatch, the currents impelling the global attack on criminal finance continue to carry it forward. Policymakers continue to insist on the "indirect liability" model imposing responsibilities on financial institutions and people involved in economic activity linked in some way to crime. Developed countries grow more emboldened to threaten or use extraterritorial authority. Would it then be possible to transform all the interest in criminal finance into a concerted effort to raise state capacity in order to make sure that the draconian laws against this activity were focused on the most egregious offenders?

One approach to increasing state capacity is to attempt to drastically increase the extent to which criminal offenses (and similarly problematic national security risks) can be detected from patterns of financial activity. ${ }^{122}$ This has far less to do with criminal penalties than with the need for dramatic increases in the government's capacity to collect and analyze domestic and international data on financial activity, as well as to isolate the activities that are most suspicious. Experts might disagree about the value of information such a system could provide and the different kinds of costs such a system would entail. But there would be little prospect of raising state capacity in this area without radically improving government's capacity to create audit trails, obtain data, and analyze patterns of transactions. Despite some improvements in this area at the margin, a revolutionary advance here is unlikely. ${ }^{123}$ Even if the focus were only on the United States, there would be substantial political opposition from financial institutions and other interested constituencies. Banks, broker-dealers, and other financial services providers would quickly see the administrative costs. Such regulations would make it still easier for government to impose indirect liability on them. Civil libertarians would also oppose major expansions in the centralization of financial information, at least in the absence of elaborate safeguards against government abuse of such information. Capacity and power problems in less-developed countries would remain a further nettlesome obstacle, since largely anonymous foreign transactions can complicate even domestic enforce-

serve. Since the threats in question are taken to involve high-cost, low probability events, voters have difficulty making reasonable calculations about the benefits of different enforcement strategies. See generally Cuéllar, Choosing Anti-terror Targets, supra note 5, at 117. Moreover, in contrast with domestic regulatory policy, neither political superiors nor citizens can easily use interest groups to police law enforcement bureaucracies because of the paucity of information.

122. Even if capacity were possible to achieve, the executive may not make the effort to develop it. Whether the politician chose to develop capacity would still depend on the politician's motivations (which may change only slowly), the extent to which the electorate will reward capacity, and the cost of developing capacity.

123. The other option, of course, is to increase the effectiveness of existing detection strategies, which depend heavily on intelligence and undercover infiltration. The problem here is that using these techniques requires some prior knowledge of the groups or individuals involved. This makes the traditional tactics very path-dependent and prone to be reactive to threats that are already known. Moreover, these methods have their own costs. While revamping the global attack would not necessarily solve all these problems, at least it provides an alternative paradigm. 
ment. ${ }^{124}$ So closing the gap by raising capacity remains, at best, an uncertain prospect. ${ }^{125}$

The same can be said for trying to close the gap by constraining the use of power without capacity. Leaders of nation-states have incentives to equate power with capacity, thereby making failures of capacity into failures to provide authorities with enough power and letting the use of legal power instill a sense of security. Unless such leaders believe that disequilibrated enforcement will directly damage their political prospects or something else they hold dear, then they will have reason to use power as an indirect way of showing desirable results. Unsophisticated citizens will buy this, but even with more sophisticated voters the dynamic may not change. The appendix provides a simple example. Supposing that a government could take certain actions to signal its commitment to use power only when it had the capacity to focus it on appropriate targets, the executive branch would only rarely have the incentive to take those actions. In general, the executive would have no reason to do so unless a few unusual political circumstances presented themselves, such as a large number of sophisticated swing-voters who cared about security and had a terribly dire view of what would happen if power and capacity were not in equipoise. Legal trends in the United States and abroad instead are consistent with the absence of political circumstances that would lead to constraints on power. Substantive criminal statutes provide for expansive and extraterritorial liability. Regulatory authority allows states to punish specific institutions or achieve the forfeiture of assets

124. An example: suppose a weapons smuggler wants to bribe inspectors of the U.S. Bureau of Customs and Border Protection to allow a shipment of explosives into the United States. Suppose further that the inspectors are somewhat risk averse, so they will demand a considerable amount (say, five times their yearly pay) to facilitate the illegal shipment. If the inspectors are paid in cash, each will have to either hoard or deposit approximately $\$ 300,000$. Hoarding it may be risky, but so would depositing the money, since large cash transactions can give rise to currency reports (or even suspicious activity reports, which might be filed even if the amount of the cash deposit does not exceed the $\$ 10,000$ reporting threshold). Conversely, the inspectors can open accounts in U.S. banks and receive a wire transfer. Although the transfer itself may be unlikely to attract suspicion, the account and its balance may trigger either a report to the IRS or a suspicious activity report. See Cuéllar, Tenuous Relationship, supra note 14, at 440 . In contrast, if the inspectors can receive anonymous deposits in secure bank accounts abroad subject to bank secrecy, then they do not need to worry about unusual concentrations of currency. The only problem remaining for the inspector is to verify that the deposit has actually been made at a reliable institution, and to figure out a scheme to enjoy the financial largesse without attracting attention.

125. Even if it were possible to design a system to police potential government abuses in this area, there is still the problem of specifying the profile of a genuinely suspicious transaction. Government officials would have at least three resources. Analysts can obtain ex post and ex ante intelligence from U.S. intelligence agencies, other states, or law enforcement agencies. The intelligence sheds light on how offenders operate. In this vein, so-called "red teams" can let the government learn without waiting for intelligence data, by getting confederates to simulate the achievement of an unlawful objective (i.e., use a fake name to set up a straw bank account to move money to a simulated terrorist cell). All of this can be supplemented with theoretical models that make assumptions about offenders, their incentives, and financial architecture to derive implications about what sort of conduct would be exceedingly unlikely to observe in a pattern of lawful transactions. For a similar approach used to identify teachers cheating when administering standardized tests to their students, see generally Brian Jacob \& Steven D. Levitt, Rotten Apples: An Investigation of the Prevalence and Predictors of Teacher Cheating (NBER Working Paper No. W 9413 2003); Brian Jacob \& Steven D. Levitt, Catching Cheating Teachers: The Results of aN Unusual Experiment in Implementing Theory (NBER Working Paper No. W9414 2003). 
with minimal evidence of wrongdoing. National security and emergency powers fill any remaining gaps in state power, allowing executive branch officials to detain people or freeze assets with low thresholds of justification.

In the meantime, governments can take some limited and less radical steps in the direction of increasing capacity. For example, governments can improve the use of existing information, regulatory rules on cross-border transactions, and high-profile changes in reporting requirements. They can see which groups change their behavior in response to the new rules (presumably the ones who fear government scrutiny most are the ones that will change their behavior) and target enforcement. But a more comprehensive capacity-building effort is a ways off, if it ever comes. The different challenges to building the regulatory system discussed above make it highly unlikely. Nor are states likely to face the pressure to roll back the laws and policies that imbue law enforcers with the power to pursue the attack on criminal finance, regardless of whether the capacity to focus that authority on the most egregious offenders is itself missing. ${ }^{126}$

\section{CONCLUSION}

There are principled reasons to pursue transnational criminal enforcement in general and to pursue the global attack on criminal finance in particular. Yet the legal arrangements created for these purposes can fail to achieve their objectives, and may sometimes even create perverse results. The problem is that changes in a nation-state's legal powers may herald only meager if any change in its capacity to reduce transnational threats. As with other challenges in transnational law enforcement, the global attack on criminal finance evinces a trend toward growth in state legal power; a trend as clear as the extent of capacity is opaque. I have explained how the gap could be narrowed in specific and rare circumstances, such as when swing voters are disproportionately sophisticated, or when investigative methods and technologies improve dramatically. Without these developments, the seductive scenario where the nation-state actually augments its capacity by expanding its legal powers will remain on the horizon, tantalizingly close-but perhaps relentlessly out of reach.

126. A rollback of power in developed countries is unlikely because: (1) the rhetoric and political logic of the global attack tends to encourage an expansion, not a contraction of those powers; and (2) there is unlikely to be a judicial remedy allowing people to police government legal powers used in the global attack on criminal finance through something akin to judicial review of prosecutorial discretion. Perhaps regulatory policy is the only area where there is likely to be continued attack on the laws used to wage the attack on criminal finance. There, powerful interest groups representing financial services providers may much prefer to have less regulation rather than more. When political shocks like the September 11, 2001 attacks on the United States drastically raise the interest in financial enforcement, even these interest groups may step aside in the face of strong political interest in further grants of regulatory authority to administrative agencies--but then they can take up the fight again before the agency to dilute the scope of regulatory power actually used. See Cuéllar, Tenuous Relationship, supra note 14, at 446-48. Nonetheless, constraints on regulatory authority may have more of a limiting effect on capacity (since regulation is primarily aimed at producing information) than on raw legal power to punish offenders, even low-level offenders, if they happen to attract attention from government. 


\section{Appendix: Signaling Capacity With a Divided Electorate and SOPHISTICATED VOTERS}

This appendix briefly considers how the mismatch between power and capacity would evolve if the executive were able to send a costly signal that demonstrated the development of capacity. I assume in this model that voters make rational expected utility calculations when deciding to vote. ${ }^{127}$ Imagine a situation where an executive, such as a president or prime minister, is trying to obtain political support. Popular support allows the executive to continue in office. It can also be translated into backing for the executive's broader legislative agenda. ${ }^{128}$ Unfortunately for the executive, the electorate is divided over his performance.

More specifically, suppose that voters can choose between the executive or a rival political candidate in an election. About 10 million people are expected to vote, so 5 million voters plus one should be necessary to win. Because of a lingering recession, about 4.5 million voters oppose the executive and only 3 million support him. These voters have made up their minds on the basis of their concerns about the economy. That leaves 2.5 million undecided voters who instead care most about national security, of which the executive needs about $80 \%$ ( 2 million plus one) to win the election. Suppose further that, of the 2.5 million undecided voters, some fraction $F$ are naivve voters. As far as the naïve voters are concerned, an executive who uses legal powers surely has developed the capacity to use those powers effectively, ${ }^{129}$ which in turn justifies supporting the incumbent. The presence of these voters makes the executive inclined to use available legal powers.

The remaining swing voters (that is, $1-F$ ) are discerning, sophisticated voters who are concerned about the possible adverse consequences of a powercapacity mismatch. To decide how to vote, the sophisticated voters consider the consequences of the package of security policies associated with the executive. These consequences are affected by the probability $p_{a}$ that there will be an adverse result because of the mismatch, and thus the probability of no adverse result is $\left(1-p_{a}\right){ }^{130}$ Meanwhile, the probability that a mismatch exists is $p_{m}$, which makes $\left(1-p_{m}\right)$ the probability that a mismatch does not exist. The sophisticated voter has the following payoffs: 2 (or $u_{e}$ ) if the executive uses power along with capacity, 1 (or $u_{-a}$ ) if the executive uses power without capacity but there is no adverse result from the mismatch, and -2 (or $u_{a}$ ) if the executive uses power without capacity and there is an adverse result from this (say, neglect of

127. See, e.g., David M. KrePs, A Course in Microeconomic Theory 76 (1990) (discussing Von Neumann-Morgenstern expected utility).

128. Cf. Douglas Rivers \& Nancy L. Rose, Passing the President's Program: Public Opinion and Presidential Influence in Congress, 29 AM. J. POL. SCI. 183, 194 (1985) ("The empirical analyses. . . indicate that, contrary to some earlier claims, public opinion is an important source of presidential influence in Congress.").

129. It is not naïve to think that naïve voters would reason this way. See supra note 102 (discussing why many voters would associate power with capacity).

130. I describe some of the adverse results of the mismatch, including perverse impacts on security and distrust of the executive, supra Part III. 
legitimate threats because of false security, or increasing polarization leading more people to support terrorism). Then the sophisticated voter employs a simple heuristic: if a vote for the incumbent produces an expected utility above a certain critical threshold $t$ (set this to 1), then she will support the incumbent. Otherwise she will vote for the challenger. Thus the sophisticated voter will support the executive if and only if:

$$
\left\{p_{m}\left[\left(p_{a} * u_{a}\right)+\left(\left(1-p_{a}\right) * u_{-a}\right)\right]+\left[\left(1-p_{m}\right) * u_{e}\right]\right\}>t
$$

Now we introduce the signaling dynamic. The executive can choose to send the electorate a signal to indicate that he is actually developing capacity. One might imagine that the signal includes some combination of (1) spending financial resources on capacity-building activities, (2) appointing competent technocrats to run law enforcement bureaucracies, (3) disclosing (i.e., declassifying) information about the extent of capacity, and (4) raising the threshold of proof necessary to use certain legal powers. Since it is costly to send the signal, the executive will not do so unless he feels like he needs to in order to achieve a victory in the election.

If the executive chooses to send the signal, this lowers $p_{m}$ from .5 to .3 . If we assume that the probability of an adverse result from the mismatch (or $p_{a}$ ) is .4 , then the sophisticated voter's utility from voting for the executive is: [(..3) $(.4)(-2)+(.3)(.6)(1)]+(.7)(2)=1.34$. Since $1.34>t$, then the sophisticated voters will vote for the executive. As long as the preceding assumptions apply and $F<2$ million plus one, then the executive will send the signal. If $F>2$ million plus one, then the executive could win the election simply by using power, and it would not be necessary to incur the cost of sending the signal. Assuming that $F$ were smaller than 2 million plus one, then the executive would have lost if he had not sent the signal, since then the sophisticated voter's utility would have been $[(.5)(.4)(-2)+(.5)(.6)(1)]+(.5)(2)=.9$, and $.9<t$.

Notice that the preceding result depends on the sophisticated voter's conclusion about the probability of an adverse result. If $p_{a}$ were only .1 and $p_{m}$ were .5 (that is, if the probability of the adverse result were lower and there were no costly signal sent), then the sophisticated voter's utility would be as follows: $[(.5)(.1)(-2)+(.5)(.9)(1)]+(.5)(2)=1.35$. The resulting utility is still higher than $t$, which means that the politician would not have to worry about sending the signal.

The upshot is that it may be possible for voters to force the executive into taking actions that might reduce the power-capacity mismatch, but only in limited circumstances. Voters can do so (1) if there is a costly signal the executive can send to show that he is strengthening capacity, (2) if the proportion of sophisticated voters is large enough so that the executive needs them to achieve a victory, (3) if the sophisticated voters think that the probability of a mismatch without the signal is quite high, and (4) if those sophisticated voters think the existence of a mismatch is sufficiently dire. That adds up to a lot of ifs. 